\title{
(Un)anticipated monetary policy in a DSGE model with a shadow banking system*
}

\author{
Fabio Verona ${ }^{\dagger} \quad$ Manuel M. F. Martins ${ }^{\ddagger} \quad$ Inês Drumond ${ }^{\S}$
}

November 14, 2012

\begin{abstract}
Motivated by the U.S. events of the 2000s, we address whether a too low for too long interest rate policy may generate a boom-bust cycle. We simulate anticipated and unanticipated monetary policies in state-of-the-art DSGE models and in a model with bond financing via a shadow banking system, in which the bond spread is calibrated for normal and optimistic times. Our results suggest that the U.S. boom-bust was caused by the combination of (i) too low for too long interest rates, (ii) excessive optimism and (iii) a failure of agents to anticipate the extent of the abnormally favorable conditions.
\end{abstract}

Keywords: DSGE model, shadow banking system, too low for too long, boom-bust

JEL codes: E32, E44, E52, G24

* This is a revised version of a paper that circulated previously under the title "Monetary policy shocks in a DSGE model with a shadow banking system". We thank three anonymous referees and the Editor Carl E. Walsh, as well as Ricardo Reis, Michael Woodford, José Jorge and seminar participants at the University of Porto and Columbia University, for useful comments and suggestions. Verona is grateful to the Fundação para a Ciência e Tecnologia for financial support (Ph.D. scholarship) and the Cournot Centre (Postdoctoral fellowship). The views expressed in this paper are those of the authors and should not be attributed to the European Commission nor to the Bank of Finland.

${ }^{\dagger}$ Bank of Finland, Monetary Policy and Research Department and University of Porto, CEF.UP (fabio.verona@bof.fi)

¥ University of Porto, Faculty of Economics and CEF.UP (mmfmartins@fep.up.pt)

$\S$ University of Porto, Faculty of Economics and CEF.UP, and DG-ECFIN, European Commission (ines.drumond@ec.europa.eu) 


\section{Introduction}

Many observers have suggested that the Federal Reserve has kept short-term interest rates too low for too long in the early 2000s, inducing the credit boom that eventually led to the post-2007 financial and economic bust known as the Great Recession. For example, Taylor (2009) shows that following the 2001 recession, the federal funds rate (FFR) has been unusually below the level prescribed by the standard Taylor rule during 2002-2005, and that in the counterfactual scenario of a Taylor rule-driven policy there would not be a comparable boom and bust.

While persistently low interest rates encourage excessive leverage and risk taking, both apparent in the 2000s boom, monetary policy has surely not been the only cause of the boom and bust. A variety of authors (from academics - e.g. Borio, 2008 and Blanchard, 2009 - to policy-makers - e.g. Trichet, 2009, Bean et al., 2010 and Bernanke, 2010) have argued that the crisis resulted from the interaction of macro and micro factors. ${ }^{1}$ Macro factors include, besides the persistently loose policy, the global imbalances and savings glut, the financial globalization, and the hangover from the Great Moderation. Micro factors include the boom of securitization, the development of a vast shadow banking system with unregulated institutions, products and markets, the increased complexity of innovative financial products with the difficulty to measure and locate financial risk, and myopic and biased incentives within financial institutions (see e.g. de Larosiere et al., 2009 and de Larosiere, 2010).

As Semmler and Bernard (2012, p. 442-3) put it, in all boom-bust episodes "the boom period triggers overconfidence, overvaluation of assets, over-leveraging, and the underestimation of risk; then follows a triggering event and the market mood turns pessimistic"; in the U.S. during the 2000s, "The complex securities (...) have, jointly with the changes in the macroeconomic environment, actually accelerated not only the boom, but also the bust".

We focus on monetary policy as one key element of the macro environment in the 2000s that may have helped triggering the boom and the bust, as its relative role is still an open issue - see e.g. the discussion in the 2010 Jackson Hole Symposium, especially between Bean et al. (2010) and Taylor (2010). In particular, the role of monetary policy in the 2000s boom-bust has not been addressed in the context of a dynamic stochastic general equilibrium (DSGE) model.

Against this background, this paper assesses the role of a too low for too long interest rate policy in the development of a boom and bust, by means of quantitative simulations of DSGE models. We start by

\footnotetext{
${ }^{1}$ See Borio (2008) and Brunnermeier (2009) for a chronology of the events relating to the subprime crises.
} 
assessing whether such a policy may trigger a boom-bust in state-of-the-art DSGE models, namely two versions of the Christiano, Motto and Rostagno (2010) model (CMR hereafter): one version including a banking system in the spirit of Bernanke et al. (1999) (henceforth BGG) and thus the well-known financial accelerator, and another version without such a sector, that corresponds closely to the Smets and Wouters (2003) model. After demonstrating their difficulty to engender financial boom-busts, we suggest a DSGE model that extends the CMR model with a shadow banking system. Specifically, our model includes a bond market populated by investment banks that finance part of the entrepreneurial sector activity. We realistically calibrate the model for normal times and for times of over-optimism, on the basis of the cyclical sensitivity of the spread in bond finance over the long run and during the 2000s' boom. When excessive optimism in financial markets is coupled with a too low for too long interest rate policy, the model generates a boom-bust in the price of capital, investment and output, associated with a strong rise in leverage alongside a fall in the bond finance spread. While the specific dynamic pattern of the boom-bust predicted by our model is more realistic for unanticipated, rather than anticipated policies (as further detailed below), our main contribution in this paper is, thus, suggesting a DSGE model that reconciles the state-of-the-art models with financial and economic boom-bust events.

To conduct our simulations, the concepts of too low and of too long must be precisely defined from the outset. We take too low to mean a constant policy interest rate below its steady-state level, not responding to economic conditions and, as such, deviating from the interest rate that would result from the monetary policy rule in force. Specifically, to approximate the events of the post-2001 boom, we simulate a FFR 100 basis points below its steady-state level: in fact, when the U.S. economy was exiting the 2001 recession, the FFR target was 2 percent and then it was further lowered to 1 percent from June 2003 onward (see figure 1). We take too long to mean that such policy interest rate path lasts for 6 quarters; the period is too lengthy in the sense that in its course, real activity and inflation start reacting, which, in normal times, would imply a reaction of monetary policy according to the rule in effect. In our simulations, the Taylor-type policy rule is only reactivated after the 6-quarters period of too low interest rate; then, the economy eventually returns to its steady state. ${ }^{2}$

In the literature, there are two traditions for simulations such as ours, namely (a) an unanticipated policy scenario and (b) an anticipated policy scenario.

\footnotetext{
2 Throughout the paper all the policy simulations will consist of a 6-quarters period of constant policy rate below its steady-state level. The length of the simulation exercise is arbitrary, but in line with comparable experiments in the literature (see e.g. Laseen and Svensson, 2011). Furthermore, we have checked that plausible variations of the simulation period (ranging from 4 to 8 quarters) do not change qualitatively the results.
} 
The unanticipated policy scenario corresponds to a simulation in the spirit of Sims and Zha (2006) and Bernanke et al. (1997, 2004), in which the short-term interest rate is kept constant and away from its steady-state level for some periods by means of a sequence of unanticipated policy shocks. Economically, it mimics a situation in which agents do not know how long the monetary ease will last, and are continuously surprised during the ease and, also, at its end. The anticipated policy scenario corresponds to a simulation in the spirit of Laseen and Svensson (2011), in which the policy projection is a credibly pre-announced policy rate path. Economically, it represents situations where the policymaker transparently announces that it plans to implement a particular policy rate path and this plan is believed and anticipated by the private sector. ${ }^{3}$

It could be argued that the unanticipated policy scenario is inappropriate for the specific case that we study. In fact, the U.S. monetary policy of the first half of the 2000s is seen by many as a case of an anticipated persistent monetary ease, as the Federal Open Market Committee (FOMC) held the FFR target consistently at 1 percent between June 2003 and June 2004, and stated on August, September, October and December 2003 that it believed policy accommodation could be maintained for a considerable period (see panel A of table 1). However, in its January and March 2004 meetings, the FOMC surprised the markets, changing the tone by delivering a new statement in which it mentioned the eventual removal of its policy accommodation. As figure 1 shows, short-term interest rates (and overall bond yields, not depicted) started increasing after March 2004, even though the FFR target has increased only in June 2004. The rise in yields thus anticipated the change in policy and happened because of an unanticipated change in the FOMC tone in January that became clear only in March.

Overall, we argue that the U.S. monetary policy in the early 2000s may not be considered clearly preannounced and entirely anticipated by economic agents. First, both the beginning and the end of the monetary ease are hard to locate precisely from the FOMC minutes, given the evolution of decisions and statements showed in panel A of table 1. Second, many agents and markets actually changed their behavior before the actual end of the 2003-2004 monetary loosening, seemingly surprised by the announcement of a change in the monetary policy stance. Hence, we consider the monetary policy of the early 2000s in the U.S. as an intermediate case between anticipated and unanticipated policy: during part of the monetary ease most agents knew that policy would be loose for a prolonged period, but it is very hard to argue that most agents knew for sure the future policy path from its outset. ${ }^{4}$

\footnotetext{
3 Another sort of possible policy simulations are those of Reis (2009), Lambertini et al. (2011) and Milani and Treadwell (2012), who study the effects of news about future monetary policies.

4 A different case could be made regarding the 2011-12 monetary ease, as, in our view, the information in panel B
} 
All considered, throughout the whole paper we implement both the unanticipated and the anticipated policy simulations, for all models considered, explicitly comparing their results. A first advantage of our approach is that considering both simulations may allow for a better approximation to the real world events of the 2000s. A second advantage is that simulating both policies allows for assessing whether the anticipation of the policy path influences its dynamic impacts; and, as a corollary, allows for drawing lessons regarding the communication of future monetary actions.

The key conclusions of the paper may be summarized as follows. First, in line with the literature, anticipated periods of too low for too long interest rates generate a very much larger and quicker boom in real activity and asset price than similar policies that are unanticipated. Second, the state-of-theart DSGE models fail to predict a sizeable boom and bust following a too low for too long monetary policy, even when extended with financial frictions. Third, our DSGE model with a shadow banking system predicts a substantial boom and bust following a too low for too long policy, when adequately calibrated with a cyclical sensitivity of the spread in bond finance in line with the 2002-2007 data, with a specific dynamic pattern that seems more realistic for unanticipated, rather than anticipated policies. Fourth, our model realistically predicts that the combination of a too low for too long interest rate policy and optimism leads to an increase in overall leverage, led by a rise in the bonds issued by the set of entrepreneurs that resort to the shadow banking system, who face a fall in the spread in bond finance during the boom. Our framework therefore highlights the central role that spreads may have on the transmission of monetary policy, as recently suggested by Gilchrist and Zakrajsek (2012b).

The remaining of the paper is structured as follows. In section 2 we simulate anticipated and unanticipated policies of too low for too long interest rates in two versions of the CMR (2010) model, after briefly discussing their main features relevant for the issue addressed in this paper. In section 3 we present our model, which extends the CMR model adding a shadow banking system as a second financial sector in addition to the standard Bernanke et al. (1999) banking system; we calibrate the model for normal times and for periods of excessive optimism such as those seen in the first part of the 2000s; and we simulate policies of too low for too long interest rates and discuss the results. Finally, we present some concluding remarks in section $4 .^{5}$

suggests that the announcements of future monetary policy by the FOMC in 2011 and 2012 conform more closely to an anticipated loosening of monetary policy. In fact, in August, September, November and December 2011, the FOMC stated that it foresaw that economic conditions were likely to warrant exceptionally low levels for the federal funds rate at least through mid-2013 and in January, March and April 2012 extended that period through late 2014.

${ }^{5}$ We present the complete model as well as some technical details in Verona et al. (2012, appendix A and B). 


\section{State-of-the-art DSGE models}

In this section we assess whether a too low for too long interest rate policy generates a boom and a bust in state-of-the-art DSGE models. In subsection 2.1 we briefly describe the models we focus on. Then in subsection 2.2 we explain the two alternative policy simulations, we show the impulse responses and discuss the results.

\subsection{The models}

The DSGE models that are currently the benchmark macroeconomic models resulted from the fusion of the Real Business Cycle models of the 1980s with the New Keynesian sticky-price models of the early 1990s. Some current versions still feature frictionless financial markets and a passive role for financial intermediaries, thus being utterly unsuitable for the analysis of financial booms and busts. This is the case of DSGE models currently used for monetary policy analysis at the main central banks

- e.g. the SIGMA model at the FED (Erceg et al., 2006), the Smets and Wouters model at the ECB (Smets and Wouters, 2003) and the Bank of England's Quarterly Model (Harrison et al., 2005).

Following the seminal paper of BGG, who include a banking sector that amplifies the effects of monetary shocks via a mechanism termed financial accelerator, the structure and role of the financial sector in DSGE models has been developed along several lines. Iacoviello (2005) extended the BGG model by introducing collateral constraints for firms, as in Kiyotaki and Moore (1997). CMR (2003, 2008 and 2010) and Goodfriend and McCallum (2007) considered a perfectly competitive banking sector that offers agents a variety of financial assets with different returns, while Kobayashi (2008) and Gerali et al. (2010) considered imperfect competition in the banking sector so as to model the setting of interest rates by banks. Curdia and Woodford (2010) allowed for a time-varying spread between deposits and lending rates. Finally, a number of papers (see, for instance, Van den Heuvel, 2008, de Walque et al., 2010, Meh and Moran, 2010 and Gertler and Karadi, 2011) studied the role of bank capital in the transmission of macroeconomic shocks.

Most importantly for our purposes, we consider and take the Financial Accelerator Model described in CMR (2010) as the state-of-the-art DSGE model. It essentially corresponds to the models in Smets and Wouters (2003) and Christiano et al. (2005) enlarged with the financial accelerator mechanism developed by BGG. 
Given the widespread awareness of the CMR model, we skip any analytical or detailed presentation, except for the retail banking system that forms its financial core. Very briefly, the model is composed of households, final- and intermediate-good firms, capital producers, entrepreneurs, banks, and government. Households consume, save and supply labor services monopolistically. They employ their savings in time deposits offered by retail banks. On the production side, monopolistically competitive intermediate-good firms use labor (supplied by households) and capital (rented from entrepreneurs) to produce a continuum of differentiated intermediate goods. Perfectly competitive final-good firms buy intermediate goods and produce the final output, which is then converted into consumption, investment and government goods. Capital producers combine investment goods with undepreciated capital purchased from entrepreneurs to produce new capital, which is then sold back to entrepreneurs. Capital services are supplied by entrepreneurs, who own the stock of physical capital and choose how intensively to use it. Entrepreneurs purchase capital using their own resources as well as external finance, namely bank loans. Government expenditures represent a constant fraction of final output and are financed by lump-sum taxes imposed to households, with the government budget systematically balanced. The Central Bank sets the nominal interest rate according to a Taylor-type interest rate rule.

Banks finance the part of the entrepreneurs' purchases of physical capital that cannot be financed with their net worth. Entrepreneurial loans are risky because the returns on their investments are subject to idiosyncratic shocks, which, if unfavorable and large enough, may lead to bankruptcy and thus incapacity to pay the required interest and re-pay their debt. Financial frictions arise because the idiosyncratic shock is observed by the entrepreneurs at no cost, while the bank has to incur in a monitoring cost to observe the shock. To deal with the problem of asymmetry in information, entrepreneurs and bank sign a debt contract, according to which the entrepreneur commits to pay back the loan principal and a non-default interest rate, unless he declares default, in which case the bank verifies the residual value of the entrepreneur's assets and takes in all of the entrepreneur's net worth, net of monitoring costs.

The retail bank funds its lending activity by issuing time deposits held by households. Although individual entrepreneurs are risky, the bank itself is not: by lending to a large number of entrepreneurs, the bank can diversify the idiosyncratic risk and thus can guarantee a safe return on households' deposits. Nevertheless, financial frictions - reflecting the costly state verification problem between entrepreneurs and the bank - imply that bank hedges against credit risk by charging a premium over 
the rate at which it can borrow from households.

As shown by Bernanke et al. (1999), the first order condition of the contracting problem yields the following relationship linking the expected return on capital $\left(R_{t+1}^{k, H R}\right)$ relative to the risk-free interest rate $\left(R_{t+1}^{e}\right)$ and the entrepreneurs' leverage ratio $\left(\frac{Q_{\bar{k}^{\prime}, t} \bar{K}_{t+1}^{H R}}{N_{t+1}^{H R}}\right)$ :

$$
\frac{E_{t}\left(1+R_{t+1}^{k, H R}\right)}{1+R_{t+1}^{e}}=\Psi\left(\frac{Q_{\bar{k}^{\prime}, t} \bar{K}_{t+1}^{H R}}{N_{t+1}^{H R}}\right)
$$

where $Q_{\overline{k^{\prime}, t}}, \bar{K}_{t+1}^{H R}$ and $N_{t+1}^{H R}$ denote, respectively, the price of capital, the entrepreneur's stock of capital and the entrepreneur's net worth and the function $\Psi$ is such that $\Psi^{\prime}>0$ for $N_{t+1}^{H R}<Q_{\bar{k}^{\prime}, t} \bar{K}_{t+1}^{H R}$. The ratio $\frac{E_{t}\left(1+R_{t+1}^{k, H R}\right)}{1+R_{t+1}^{e}}$, which Bernanke et al. (1999) interpreted as the external finance premium faced by the entrepreneur, depends positively on the entrepreneur's leverage ratio. All else equal, higher leverage means higher exposure, implying a higher probability of default and thus a higher credit risk, which leads the bank to require a higher return on lending.

In the CMR model, the cost of borrowing fluctuates endogenously with the cycle due to two general equilibrium mechanisms.

The first, and quantitatively more important, is the BGG financial accelerator effect, whereby changes in the asset price change the value of the collateral that the entrepreneur can pledge and, thus, the contractual loan rate. A positive shock to the asset price, resulting for instance from a monetary easing, increases the entrepreneur's net worth and decreases the external finance premium, which in turn stimulates the demand for investment. The increase in net worth also reduces the expected default probability and allows the entrepreneur to take on more debt and to further expand investment. Hence, an accelerator effect arises, as the boom in investment raises the asset price, further pushing up the entrepreneur's net worth and, thus, investment.

The second mechanism, quantitatively less important and absent in BGG, is a Fisher (1933) debt deflation effects that arise from the fact that debt contracts are set in nominal terms. Since the return received by households on their deposits is nominally non-state contingent, while loans to entrepreneurs are state-contingent, unexpected movements in the price level change the ex-post real burden of entrepreneurial debt and, hence, the entrepreneur's net worth. For example, after an unexpected increase in inflation, the real resources transferred from the entrepreneur to households fall and consequently 
the entrepreneur's net worth increases. ${ }^{6}$

The financial accelerator and Fisher effect reinforce each other in the case of shocks that move inflation and output in the same direction (e.g. monetary policy shocks), whereas they counterbalance each other in the case of shocks that move inflation and output in opposite directions (e.g. technology shocks). Evidently, a persistently loose monetary policy should have amplified effects in the CMR model, compared with a similar model without the banking sector.

In what follows, we simulate the too low for too long interest rate policies in the version of the CMR that includes the BGG financial accelerator (henceforth CMR-FA) and in a version without the retail banking system, which is very close to the model of Smets and Wouters (2003) (termed CMR-Simple). ${ }^{7}$ The purpose is to isolate the effect of the retail banking system in the transmission of the persistently loose monetary policy, as well as to assess whether it depends on the ability of agents to anticipate the policy.

\subsection{Policy simulations}

We now conduct two simulations for each model, namely the unanticipated policy scenario and the anticipated policy scenario. In both, the policy (risk-free) nominal interest rate is held constant below its steady-state level by 100 basis points for 6 quarters; afterward, the nominal interest rate set by the central bank re-starts being determined by the following Taylor-type policy rule, which includes interest rate smoothing and responses of the policy rate to deviations of expected inflation $\left(E_{t} \pi_{t+1}\right)$ and current output $\left(Y_{t}\right)$ from their steady states:

$$
R_{t}^{e}=\tilde{\rho} R_{t-1}^{e}+(1-\tilde{\rho})\left[R^{e}+\alpha_{\pi}\left(E_{t} \pi_{t+1}-\bar{\pi}\right)+\alpha_{y}\left(Y_{t}-\bar{Y}\right)\right]+\varepsilon_{t}^{M P}
$$

where $R^{e}, \bar{\pi}$ and $\bar{Y}$ are the steady-state values of $R_{t}^{e}, \pi_{t}$ and $Y_{t}$, respectively, $\alpha_{\pi}$ and $\alpha_{y}$ are the weights assigned to expected inflation and output, $\tilde{\rho}$ captures interest rate smoothing and $\varepsilon_{t}^{M P}$ is a monetary policy shock. Based on CMR, we calibrate $\tilde{\rho}$ to 0.88 and $\alpha_{\pi}$ and $\alpha_{y}$ to 1.82 and 0.11 , respectively (we maintain this policy rule throughout the whole paper).

\footnotetext{
${ }^{6}$ Iacoviello (2005) and Gerali et al. (2010) also consider this effect.

7 Compared to the original CMR model, both versions also exclude long-run growth, the fixed cost in the production function and distortionary taxes on capital, labor income and household consumption. While not changing the model's dynamic responses to monetary policy shocks, these simplifications reduce its complexity. The Dynare codes for replicating all the results in this paper are available from the authors upon request.
} 
The unanticipated policy simulation mimics a situation in which agents do not know how long the monetary ease will last, and are continuously surprised during the whole policy path. Technically, the policy interest rate is held constant by means of a sequence of shocks $\varepsilon_{t}^{M P}$ determined residually at each of the 6 periods of the simulation. These are unanticipated by economic agents, who then change their inter-temporally optimizing decisions each period accordingly. The anticipated policy simulation mimics a situation in which the policy-maker announces a specific policy rate path and it is entirely believed by the private sector. Technically, the policy path is written as a function of the initial state of the economy, which includes a set of anticipated shocks to the policy rule consistent with the announced path, i.e. the set $\left[\varepsilon_{t}^{M P}\right]_{t=1}^{6}$ is perfectly known to agents at $t=0$. As agents know the shocks and the policy rate path from the outset, including the return of monetary policy to the prevailing rule after the ease, they adjust their optimizing decisions immediately after the credible announcement.

Figure 2 plots the impulse response functions of the most important variables - nominal interest rate, output, investment, inflation, price of capital (the model's indicator for the price of assets in the financial market) and, for the CMR-FA version, the interest rate on loans and the entrepreneurs' leverage and loans.

A first conclusion that stands out is that anticipated policies (panel A) generate a much larger and immediate response of macroeconomic and financial variables than unanticipated policies (panel B). This is in line with results elsewhere in the literature (see Laseen and Svensson, 2011, fig. 3), and it was expected: when policy is anticipated, agents change immediately their decisions knowing that the nominal interest rate will be below its steady-state level and unresponsive to the state of the economy for 6 quarters. Output, investment and inflation react with a hump-shaped pattern in both simulation scenarios, even though peaking sooner and at a very much higher level when policy is anticipated. While the behavior of net worth is similar, the price of capital behaves quite differently in the two simulations: when the too low for too long interest rate policy is unanticipated, it jumps slightly on impact and then is virtually constant until the end of the monetary ease, then re-converging to its steady-state level; when policy is anticipated, the price of capital jumps markedly on impact (by a factor of 5 compared to the alternative scenario) and then falls rapidly and goes through a small bust, before converging to the steady state. Clearly, no scenario predicts a gradual build up of the price of capital as apparently was the case during the 2000s boom.

A second conclusion is that the BGG's financial accelerator has a rather limited amplification effect 
in the CMR model. The impulse response functions of output, inflation and price of capital in the CMR-FA and the CMR-Simple model are quite similar, irrespectively of the (un)anticipation of the monetary policy path. When policy is anticipated, in the model with the banking system there is a larger jump on impact of the price of capital, while when policy is unanticipated not only the initial jump is slightly larger but there is also some build up in the price of capital until the end of the monetary ease - but the differences are not striking. In both policy scenarios, investment reacts with a hump-shaped pattern, and it peaks at a rather higher level in the CMR-FA model - here, the difference is more noteworthy.

A third conclusion, related with the previous, is that including a BGG banking system in the stateof-the-art DSGE model is not sufficient for a period of too low for too long interest rates to induce a dynamics of the price of capital and investment - let alone output and inflation - akin to the one seen in the boom and bust of the 2000s.

A fourth and key conclusion is that, irrespectively of the ability of agents to anticipate the policy path, the CMR-FA model predicts that a too low for too long interest rate policy induces a fall in the leverage of entrepreneurs during the period of booming investment, output and prices (of final good and of capital). This is clearly at odds with the huge overall increase in leverage that occurred in the U.S. during the first half of the 2000s. In fact, it is at odds with the stylized facts of all boom episodes, namely overconfidence, overvaluation of assets, over-leveraging, and the underestimation of risk (Semmler and Bernard, 2012). We thus conclude that the state-of-the-art DSGE model has important difficulties to scrutinize the boom and bust events such as the one in the U.S. during the 2000 s. $^{8}$ Hence the motivation for our model proposed and analyzed in the next section.

\section{A DSGE model with a shadow banking system}

In this section we suggest a DSGE model that realistically features over-optimism and over-leveraging in the course of the boom. The section has three subsections. In the first, we present the new part of the model, namely the shadow banking system that parallels the retail banking system; special attention is given to the modeling of normal times as opposed to times of optimism associated with booms. In

\footnotetext{
8 Descriptions of the U.S. boom-bust of the 2000s typically emphasize the excessive risk taking and leverage of financial institutions, rather than of non-financial economic agents (as are the entrepreneurs in these DSGE models). Stylized as the model might be with this respect, one should not forget that the financial intermediaries' leverage is a sign of the leverage took on by the ultimate economic agents, firms and households who buy goods and services.
} 
the second, we present the calibration, again focusing on the working of the shadow banking system in normal and optimistic times. Finally, we present the simulation of anticipated and unanticipated monetary policies of too low for too long interest rates and discuss the results.

\subsection{The model}

Figure 3 sketches the structure of the model. Agents and flows depicted in solid lines correspond to the CMR-FA model discussed in section 2, while dashed lines represent the innovations of our model. In short, we augment the CMR-FA model with a shadow banking system, which may be thought of as representing the intermediation of funds between households and part of the entrepreneurial sector through securitized finance. ${ }^{9}$ Our model's financial system is thus composed of two different financial sectors - loan and bond market - with different financial intermediaries - retail and investment banks that intermediate financial flows (granting loans and underwriting bonds) between households (lenders) and two groups of entrepreneurs (borrowers).

The setting up of the shadow banking system is paralleled by the division of the entrepreneurial sector into two groups, each having access to one of the sources of external funding. Usually, in the corporate finance literature (see, among many others, Diamond, 1991, Chemmanur and Fulghieri, 1994, Holmstrom and Tirole, 1997, Berlin and Loeys, 1988, Bolton and Freixas, 2000, 2006 and Hale, 2007), firms are segmented by risk classes in their choice of funding, with safer firms having access to bond financing and riskier firms resorting to bank loans. Accordingly, we assume that riskier entrepreneurs (henceforth HR, to denote high risk) obtain financing via retail bank loans, while safer entrepreneurs (henceforth LR - low risk) issue bonds resorting to investment banks. ${ }^{10}$ The entrepreneurs that resort to retail bank financing have higher risk because, as seen in section 2 , they may default due to a low

\footnotetext{
9 The expression "shadow banking system" has been suggested originally by Paul McCulley of PIMCO at the 2007 Jackson Hole conference, where he defined it as "the whole alphabet soup of levered up non-bank investment conduits, vehicles, and structures" (McCulley, 2007, pag. 2). The shadow banking system in our model is very stylized and does not come anywhere near the variety and complexity of products, institutions and markets that exist in reality (see Pozsar et al., 2010 for a comprehensive and up-to-date description of the shadow banking system). For example, during the 2000s' boom in the U.S., a large part of assets intermediated by the shadow banking system were related to the housing market, involving mortgage-backed securities, while our model does not feature a housing market (for a recent analysis of expectations-driven boom-busts in the housing market, see e.g. Lambertini et al., 2012). The modeling of the shadow banking system stems from the macroeconomic nature of our model: adding into a DSGE model a too complex shadow banking system would be highly demanding and hardly cost-effective given that we want to focus on aggregate phenomena.

10 Typically, a firm going public hires an investment bank to sell its securities. The investment bank (the underwriter) acts as an intermediary between the issuing firm and the ultimate investors. The most common type of underwriting arrangement is the firm commitment underwriting, according to which the underwriter buys the entire stock of bonds from the firm and resells it to investors at a higher price (i.e., at a lower interest rate). This spread represents the investment bank's profits. See Ellis et al. (2000) for an in-depth analysis of the underwriting process.
} 
realization of the productivity shock. We model the remaining set of entrepreneurs as safer assuming that they always have enough net worth to repay their debt, i.e. they never default. Accordingly, in equilibrium, safer entrepreneurs obtain finance at a lower interest rate than riskier entrepreneurs.

The shadow banking system is populated by a continuum of monopolistic competitive investment banks, who set the coupon rate on bonds seeking to maximize profits. These are then rebated to the stockholders, i.e. to the households. The assumption of monopolistic competition in the bond market is consistent with the empirical evidence about the U.S. market of bond underwriting. For example, Fang (2005) shows that the largest five investment banks underwrite more than $60 \%$ of all deals, and the largest fifteen banks account for roughly $95 \%$ of all deals. The decision of the bond coupon rate is taken by the investment bank manager, whom we call henceforth the underwriter. In our framework, the coupon interest rate of the bond is set as a markup over the risk-free interest rate. We defer to the end of this subsection and, most especially, to the next subsection, details on the spread in bond finance. For now, we make three brief notes about the bond finance spread. First, its behavior will be crucial for the dynamics of the model. Second, the data clearly reveal that it is time-varying and counter-cyclical (see figure 4). Third, the data also tell that in times of over-optimism, the elasticity of the spread to the business cycle is larger than in normal times.

In what follows we only describe the shadow banking system and the agents involved in this new block of the economy. The rest of the model is standard in the literature (corresponds to the CMR-FA model) and is set out in Verona et al. (2012, appendix A).

We assume that riskier entrepreneurs are a fraction $\eta$ of the total population of entrepreneurs, so that the share of safer entrepreneurs is $1-\eta$. The superscripts " $L R$ " and " $L R, l$ " refer to variables associated with the safer entrepreneurs.

\section{Safer entrepreneur's profit maximization problem}

At the beginning of period $t$, the representative $l$-th LR entrepreneur provides capital services to intermediate-good firms. Capital services, $K_{t}^{L R, l}$, are related to the entrepreneur's stock of physical capital, $\bar{K}_{t}^{L R, l}$, according to $K_{t}^{L R, l}=u_{t}^{L R, l} \bar{K}_{t}^{L R, l}$, where $u_{t}^{L R, l}$ denotes the level of capital utilization. When choosing the capital utilization rate, the entrepreneur takes into account the increasing and

convex utilization cost function $a\left(u_{t}^{L R, l}\right)$, that denotes the cost, in units of final goods, of setting the 
utilization rate to $u_{t}^{L R, l}$.11 $^{11}$

Then, at the end of period $t$, the entrepreneur sells the undepreciated capital to capital producers at price $Q_{\overline{k^{\prime}}, t}$, pays the nominal coupon rate $\left(R_{t}^{\text {coupon }}\right)$ on bonds issued and purchases new capital from capital producers at price $Q_{\overline{k^{\prime}}, t}$. The capital acquisition is financed partly by his net worth, $N_{t+1}^{L R, l}$, and partly by issuing new bonds. The amount of bonds issued, $B I_{t+1}^{L R, l}$, is given by:

$$
B I_{t+1}^{L R, l}=Q_{\bar{k}^{\prime}, t} \bar{K}_{t+1}^{L R, l}-N_{t+1}^{L R, l}
$$

The entrepreneur's time- $t$ profits, $\Pi_{t}^{L R, l}$, are given by:

$$
\begin{aligned}
\Pi_{t}^{L R, l}= & {\left[u_{t}^{L R, l} r_{t}^{k, L R}-a\left(u_{t}^{L R, l}\right)\right] \bar{K}_{t}^{L R, l} P_{t}+(1-\delta) Q_{\bar{k}^{\prime}, t} \bar{K}_{t}^{L R, l} } \\
& -Q_{\bar{k}^{\prime}, t} \bar{K}_{t+1}^{L R, l}-R_{t}^{\text {coupon }}\left(Q_{\bar{k}^{\prime}, t-1} \bar{K}_{t}^{L R, l}-N_{t}^{L R, l}\right),
\end{aligned}
$$

where $r_{t}^{k, L R}$ denotes the real rental rate, $P_{t}$ the price of the final good and $\delta$ the depreciation rate.

In period $t$ the entrepreneur chooses the capital utilization rate and the desired capital to use in period $t+1$ so as to maximize $\Pi_{t}^{L R, l}$, taking as given the coupon rate to be paid on the bonds issued. The first order conditions with respect to $u_{t}^{L R, l}$ and $\bar{K}_{t+1}^{L R, l}$ are, respectively:

$$
\begin{gathered}
r_{t}^{k, L R}=a^{\prime}\left(u_{t}^{L R, l}\right) \\
Q_{\overline{k^{\prime}, t}}=\beta E_{t}\left\{\left[u_{t+1}^{L R, l} r_{t+1}^{k, L R}-a\left(u_{t+1}^{L R, l}\right)\right] P_{t+1}+(1-\delta) Q_{\overline{k^{\prime}, t+1}}-R_{t+1}^{\text {coupon }} Q_{\overline{k^{\prime}, t}}\right\} .
\end{gathered}
$$

Equation (2) states that the rental rate on capital services equals the marginal cost of providing those services. As the rental rate increases it becomes more profitable to use capital more intensively up to the point where the extra profits match the extra utilization costs. The capital Euler equation (3) equates the value of a unit of installed capital at time $t$ to the expected discounted return of that extra unit of capital in period $t+1$.

The entrepreneur's equity at the end of period $t, V_{t}^{L R, l}$, is given by

$V_{t}^{L R, l}=\left\{\left[u_{t}^{L R, l} r_{t}^{k, L R}-a\left(u_{t}^{L R, l}\right)\right] P_{t}+(1-\delta) Q_{\bar{k}^{\prime}, t}\right\} \bar{K}_{t}^{L R, l}-\left(1+R_{t}^{\text {coupon }}\right)\left(Q_{\bar{k}^{\prime}, t-1} \bar{K}_{t}^{L R, l}-N_{t}^{L R, l}\right)$

11 The functional form that we use is $a\left(u_{t}^{L R, l}\right)=\frac{r^{k, L R}}{\sigma_{a}^{L R}}\left[\exp ^{\sigma_{a}^{L R}\left(u_{t}^{L R, l}-1\right)}-1\right]$, where $r^{k, L R}$ is the steady-state value of the rental rate of capital, $a(1)=0, a^{\prime \prime}(1)>0$ and $\sigma_{a}^{L R}=a^{\prime \prime}(1) / a^{\prime}(1)$ is a parameter that controls the degree of convexity of costs. 
The first term represents the rental income of capital, net of utilization costs, and the proceeds from selling undepreciated capital to capital producers. The second term represents the payment (coupon and principal) of the bonds issued in period $t-1$.

To avoid a situation in which the entrepreneur accumulates enough net worth to become self-financed, we assume a constant probability of death: in each period, the entrepreneur exits the economy with probability $1-\gamma^{L R}$. In that case, he rebates his equity to households in a lump-sum way:

$$
\text { transfer to households }=\left(1-\gamma^{L R}\right) V_{t}^{L R, l} .
$$

To keep the entrepreneurs' population constant, a new entrepreneur is born with probability $1-\gamma^{L R}$.

The total entrepreneur's net worth $N_{t+1}^{L R, l}$ combines total equity and a transfer, $W_{t}^{e, L R, l}$, received from households, which corresponds to the initial net worth necessary for the entrepreneur's activity to start. The law of motion for the entrepreneur's net worth is:

$$
N_{t+1}^{L R, l}=\gamma^{L R} V_{t}^{L R, l}+W_{t}^{e, L R, l}
$$

\section{Safer entrepreneur's financing cost minimization problem}

There is a continuum of investment banks, indexed by $z \in[0,1]$, and each investment bank $z$ has some market power when conducting its intermediation services. An entrepreneur seeking an amount of borrowing for period $t+1$ equal to $B I_{t+1}^{L R, l}$, defined by (1), would allocate his borrowing among different investment banks, $B I_{t+1}^{L R, l}(z)$, so as to minimize the total repayment due. At the end of period $t$, the entrepreneur chooses how much to borrow from bank $z$ by solving the following problem:

$$
\min _{B I_{t+1}^{L R, l}(z)} \int_{0}^{1}\left[1+R_{t+1}^{\text {coupon }}(z)\right] B I_{t+1}^{L R, l}(z) d z
$$

subject to a Dixit-Stiglitz aggregator

$$
B I_{t+1}^{L R, l}=\left\{\int_{0}^{1}\left[B I_{t+1}^{L R, l}(z)\right]^{\frac{c_{\varepsilon_{t}}^{\text {coupon }}-1}{\varepsilon_{t+1}^{\text {coupon }}}} d z\right\}^{\frac{\varepsilon_{t+1}^{\text {coupon }}}{\varepsilon_{t+1}^{\text {coupon }}-1}}
$$

where $R_{t+1}^{\text {coupon }}(z)$ is the interest rate charged by the $z$-th bank and $\varepsilon_{t+1}^{\text {coupon }}>1$ is the time-varying interest rate elasticity of the demand for funds. The first order condition yields the following entrepreneur's 
demand for funds:

$$
B I_{t+1}^{L R, l}(z)=\left(\frac{1+R_{t+1}^{\text {coupon }}(z)}{1+R_{t+1}^{\text {coupon }}}\right)^{-\varepsilon_{t+1}^{\text {coupon }}} B I_{t+1}^{L R, l}
$$

where $R_{t+1}^{\text {coupon }}$ is the nominal average coupon rate prevailing in the market at time $t+1$, defined as:

$$
1+R_{t+1}^{\text {coupon }}=\left\{\int_{0}^{1}\left[1+R_{t+1}^{\text {coupon }}(z)\right]^{1-\varepsilon_{t+1}^{\text {coupon }}} d z\right\}^{\frac{1}{1-\varepsilon_{t+1}^{\text {coupon }}}}
$$

As expected, the funds demand curve has a negative slope: when the interest rate that the $z$-th bank sets increases relatively to the average rate, the entrepreneur wishes to borrow less funds from that particular bank.

\section{Investment banks}

The investment banks are owned by households. To keep the analysis as simple as possible, we follow the recent DSGE banking literature and assume perfect competition in the market for households' deposits in these banks (see e.g. Kobayashi, 2008). We rule out the entry and exit of investment banks. The investment bank therefore maximizes its profits, taking as given the return to pay to the households. In Verona et al. (2012, appendix A) we show that the required return on bonds by households is equal to the risk-free rate, i.e. the central bank nominal interest rate.

At the end of period $t$, the $z$-th investment bank thus solves the following profit maximization problem:

$$
\begin{aligned}
\max _{R_{t+1}^{\text {coupon }}(z)} \Pi_{t+1}^{I B}(z)=\left\{\left[1+R_{t+1}^{\text {coupon }}(z)\right] B I_{t+1}^{L R, l}(z)-\left[1+R_{t+1}^{e}\right] B I_{t+1}^{L R, l}(z)\right\} \\
\text { subject to } \quad B I_{t+1}^{L R, l}(z)=\left(\frac{1+R_{t+1}^{\text {coupon }}(z)}{1+R_{t+1}^{\text {coupon }}}\right)^{-\varepsilon_{t+1}^{\text {coupon }}} B I_{t+1}^{L R, l} .
\end{aligned}
$$

Deriving the first-order condition, imposing a symmetric equilibrium and rearranging yields

$$
1+R_{t+1}^{\text {coupon }}=\frac{\varepsilon_{t+1}^{\text {coupon }}}{\varepsilon_{t+1}^{\text {coupon }}-1}\left(1+R_{t+1}^{e}\right)
$$

that is, the coupon rate is a time-varying markup, $\frac{\varepsilon_{t+1}^{\text {coupon }}}{\varepsilon_{t+1}^{\text {coupon }}-1}$, over the policy interest rate. The profits of the investment banking sector in period $t+1$ are given by $\Pi_{t+1}^{I B}=\left(R_{t+1}^{\text {coupon }}-R_{t+1}^{e}\right)(1-\eta) B I_{t+1}^{L R, l}$ and are rebated to households.

The spread in bond finance, i.e. the spread between the bond coupon rate and risk-free nominal 
interest rate is

$$
\operatorname{spread}_{t+1} \equiv R_{t+1}^{\text {coupon }}-R_{t+1}^{e}=\frac{1}{\varepsilon_{t+1}^{\text {coupon }}-1}\left(1+R_{t+1}^{e}\right)
$$

Equation (5) is crucial for the dynamic behavior of the model. If the elasticity of the demand for funds in the bond market was constant, the model would predict that the spread in bond finance would depend only on the policy interest rate. Yet, it is well-known that spreads co-move with the business cycle overall, from spreads between interest rates on short term commercial paper and Treasury bills (see e.g. Friedman and Kuttner, 1998) to spreads between long corporate bond yields and long Treasury yields (see e.g. Gertler and Lown, 1999). We do not attempt to provide micro-foundations for the counter-cyclical behavior of the spread in bond finance, as their multiple and complex determinants would be very hard to pin down in a DSGE model - thus deferring that task to more stylized models of finance. Rather, we adopt an empirical approach and calibrate the counter-cyclical behavior of the spread in bond finance according to U.S. data, as further detailed in the next subsection. We firstly specify a linear relation between the elasticity of demand for funds in the bond market and the cyclical state of the economy, which rules the baseline behavior of the spread in bond finance. In addition, motivated by the above refered fact that boom periods trigger overconfidence, overvaluation of assets, over-leveraging, and the underestimation of risk (see e.g. Semmler and Bernard, 2012) we distinguish between normal times and periods of optimism (associated with financial booms). To do so, we adopt a two-tier approach to model the counter-cyclical behavior of the spread in bond finance.

First, we specify the following baseline relation between the elasticity of the demand for funds in bond finance and the output gap:

$$
\varepsilon_{t+1}^{\text {normal }}=\bar{\varepsilon}+\alpha_{1}\left(Y_{t}-\bar{Y}\right)
$$

so that the interest rate on bonds in normal times, $R_{t+1}^{\text {coupon,normal }}$, is given by

$$
1+R_{t+1}^{\text {coupon, normal }}=\frac{\varepsilon_{t+1}^{\text {normal }}}{\varepsilon_{t+1}^{\text {normal }}-1}\left(1+R_{t+1}^{e}\right)
$$

and the spread during normal times is

$$
\operatorname{spread}_{t+1}^{\text {normal }}=\frac{1}{\varepsilon_{t+1}^{\text {normal }}-1}\left(1+R_{t+1}^{e}\right)
$$

As further explained below, calibrating equation (6) with very long historical time series for the U.S., allows us to deem equations (6)-(8) as driving the cyclical sensitivity of the spread in normal times. 
The second tier of our modeling strategy for the behavior of the spread in bond finance consists of proposing two additional equations that are inactive in normal times, but are activated in times of over-optimism. The associated under-estimation of risk and excessive leverage inexorably co-exist with abnormally low spreads in securitized finance, as has been the case in the U.S. 2000s' boom (see e.g. Semmler and Bernard, 2012). A multiplicity of factors may have triggered the over-confident behavior and it is beyond the scope of this paper to suggest thorough micro-foundations for over-confidence. Rather, we distillate those multiple factors in what we call optimism: whenever the underwriter becomes optimistic, he underwrites bonds at a lower that the normal coupon rate.

We model this second tier with two additional equations.

The first states that the underwriter becomes optimistic whenever the entrepreneurs are able to pledge a higher (than the steady-state level) value as collateral. To see the potential of this assumption, note that this could happen, for example, because the market price of collateral is increasing. We thus model underwriter's optimism, $\chi_{t}$, as a positive function of the entrepreneur's net worth. Moreover, to take into account the fact that human beliefs are very persistent (Kurz and Motolese, 2011), we furthermore model optimism as an $A R(1)$ process with high persistence. Accordingly, the law of motion for optimism is given by

$$
\chi_{t}=\rho_{\chi} \chi_{t-1}+\left(1-\rho_{\chi}\right)\left[\bar{\chi}+\alpha_{2}\left(N_{t+1}^{L R, l}-N^{L R, l}\right)\right]
$$

where $\bar{\chi}, \bar{\chi}=0$, is the steady-state level of optimism, $\rho_{\chi}$ captures the degree of persistence in optimism and $\alpha_{2}>0$ the sensitivity of optimism with respect to the deviation of the entrepreneur's net worth from its steady-state value $\left(N^{L R, l}\right)$.

The second states that whenever the underwriter is optimistic, the elasticity of the demand for funds in the bond market deviates positively from its normal times level:

$$
\varepsilon_{t+1}^{\text {optimistic }}=\varepsilon_{t+1}^{\text {normal }}\left(1+\chi_{t}\right)
$$

The optimistic elasticity results in a lower coupon rate, which may be seen substituting (10) into (4), yielding the following expression

$$
1+R_{t+1}^{\text {coupon }, \text { optimistic }}=\frac{\varepsilon_{t+1}^{\text {normal }}\left(1+\chi_{t}\right)}{\varepsilon_{t+1}^{\text {normal }}\left(1+\chi_{t}\right)-1}\left(1+R_{t+1}^{e}\right)
$$


where $R_{t+1}^{\text {coupon,optimistic }}$ is the coupon rate that the optimistic underwriter sets on the bonds issued. Comparing (11) and (7), it is clear that the optimistic underwriter underwrites bonds at a lower than the normal interest rate.

To summarize: in the steady state, when optimism and the output gap are null, the spread in bond finance is given by a constant elasticity of the demand and depends only on the central bank interest rate; when the economy records cyclical fluctuations but times are normal as regards the financial markets and economic mood, the spread moves counter-cyclically, as the elasticity moves with the output gap according to equation (6); when some set of factors induces over-optimism, perceived as increases in the net worth of the entrepreneurial sector, we allow the elasticity of demand for funds in the bond market to change with optimism (in addition to changing with the cyclical state of the economy) and therefore the discount on bond finance increases further than would happen merely because of the business cycle.

\subsection{Calibration}

The model is calibrated for the U.S. economy assuming the quarter as the time unit. We focus on the calibration of the parameters associated with the shadow banking system and the fraction of entrepreneurs that employ bond finance - the innovative part of our model. The values of the remaining parameters are calibrated in line with the established New Keynesian literature and are shown in table 2. Tables 3 and 4 report the steady-state implications of the model and their empirical counterparts. These tables show how the model successfully reproduces most of the salient features of the U.S. economy, namely key macroeconomic and leverage ratios, interest rates and, importantly, its financial market structure.

The share of entrepreneurs that resort to the retail banking system for finance, $\eta$, is set to 0.278 , which (given the bond and loan amounts in the steady state) allows us to exactly match the ratio of bank to bond finance in the U.S. economy (as reported by De Fiore and Uhlig, 2011). ${ }^{12}$

Equations (6) and (8) show that the steady-state bond spread depends on the interest rate elasticity $\bar{\varepsilon}$.

\footnotetext{
12 The values of the parameters related with this part of the entrepreneurial sector are primarily chosen to match the cost of external finance, i.e. the contractual, no-default interest rate on entrepreneurial debt $\left(Z_{t}\right.$ resulting from equation (A.6) in Verona et al., 2012). Setting the fraction of realized payoffs lost in bankruptcy, $\mu$, to 0.15 and the standard deviation of the entrepreneur idiosyncratic productivity shock, $\sigma$, to 0.55 yields $Z=6.81 \% /$ year. This is in line with the data and is realistically above the steady-state risk-free interest rate, which is $5.16 \%$, given that we set the discount factor $\beta$ to 0.9875 . Moreover, it reasonably guarantees that, in equilibrium, bond financing is cheaper than bank financing. To match the observed leverage ratio, we set the survival rate $\gamma^{H R}$ to 0.97 .
} 
Chen et al. (2007) report an average annual yield spread of $A A A$ bonds of 84 basis points. Accordingly, we set $\bar{\varepsilon}$ to 510 , so that the annual bond spread is around 84 basis points in the steady state, and the steady-state coupon rate paid by the safer entrepreneurs is $5.99 \% / y e a r$. To match the average leverage ratio in the data, we set the survival probability $\gamma^{L R}$ to 0.96 .

When the economy is not in the steady state, the spread in bond finance exhibits a counter-cyclical dynamics. Our two-tier approach to modeling the behavior of the bond spread requires calibrating (i) parameter $\alpha_{1}$ in equation (6), to govern the behavior of the spread in normal times, and (ii) parameter $\alpha_{2}$ in equation (9), to add a specific behavior of the spread in times of over-optimism.

We calibrate the parameter $\alpha_{1}$ using very long historical time series for the U.S., so that the equation may actually be thought of as driving the cyclical sensitivity of the bond spread in normal times.

Data are from the U.S. for 1953 through 2011, with a quarterly periodicity. Regarding the spread we follow a recent literature that focuses on yields of corporate bonds with long average residual maturity vis-a-vis yields of government bonds with comparable maturity (see Gilchrist et al., 2009 and Gilchrist and Zakrajsek, 2012a). Specifically, we use the difference between (quarterly averages of) the Moody's Seasoned Baa Corporate Bond yields and the 10-Year Treasury constant maturity yields. To measure the business cycle we consider the official output gap, i.e. the difference between real output and the real potential output estimated by the Congressional Budget Office. Figure 4 shows the long time series of bond spread and output gap, as well as the official dating of U.S. recessions by the NBER.

On average, in the 10 recessions identified by the NBER during this period, each percentage point of decrease in the output gap has been associated with an increase in the bond spread of 0.21 percentage points. ${ }^{13}$ Consistently, an OLS regression of the spread on a constant and the output gap yields an estimate of -0.2 for the coefficient associated to the gap. To establish the dynamics that our model should approximate, we estimate a VAR model of inflation, output gap, spread and the federal funds rate, finding that a monetary policy shock generates a counter-cyclical dynamics of the spread which, at the height of the impacts (4 quarter lag for output and 6 quarter lag for the spread), corresponds to a rise in the spread of 0.26 percentage points per each percentage point of decrease in the output gap. ${ }^{14}$ Overall, we find it reasonable to calibrate the model so that in its baseline specification - when

\footnotetext{
13 See the business cycle dating at http://www.nber.org/cycles/cyclesmain.html. For each recession, we compute the difference between the bond spread (gap) in the last quarter of the recession and its value in the quarter prior to the beginning of the recession. The behavior of spreads during expansions is essentially symmetric.

14 All data have been downloaded from FRED on March 2012 (http://research.stlouisfed.org/fred2/). The series references are: BAA and GS10 (corporate and treasury yields); GDPC1 and GDPPOT (real and potential output); FEDFUNDS (effective federal funds rate); and PCECTPI (personal consumption expenditures price index). The monthly
} 
optimism is absent - a monetary policy shock causes the output gap and the spread to move in opposite directions with each percentage point of deviation of real output from its steady-state level associated with 0.22 percentage points of deviation of the corporate bond coupon rate from the risk-free interest rate. Such elasticity roughly corresponds to the OLS estimate, only slightly magnified to account for the higher values given by the simple peak-trough analysis and the VAR estimates.

Simulating our model, it turns out that for $\alpha_{1}=30000$ an expansionary monetary policy shock generates a hump-shaped response of the output gap and (in the opposite direction) of the bond spread, with peak and trough respectively at quarters 3 and 4 (a dynamics fairly in line with the data) and an implied output gap-elasticity of the spread of -0.22 at both quarters. We thus assume $\alpha_{1}=30000$ for the calibration of the behavior of the spread in bond finance in normal times.

We then calibrate the parameter $\alpha_{2}$ considering only data for the 2002-2007 period, as the equations driven by this parameter (9-11) are meant to capture times of over-optimism. As figure 4 shows, in the 2000s the spread has been abnormally counter-cyclical: in fact, in the expansion identified by the NBER during this period (2002:Q1-2007:Q3), each percentage point of increase in the output gap has been associated with a decrease in the bond spread of 0.95 percentage points. For 2002:Q1-2008:Q2, a period that encompasses the boom and does not include the financial crisis, an OLS regression of the spread on a constant and the output gap yields an estimate of -0.7 for the coefficient associated to the gap.

We thus simulate the model in search for the value for $\alpha_{2}$ that mimics such degree of sensitivity. It turns out that for $\alpha_{2}=24$ an expansionary monetary policy shock generates a hump-shaped response of the output gap and a symmetric response of the bond spread, with peak and trough respectively at quarters 3 and 5 and an implied output gap-elasticity of the spread of -0.72 at both quarters.

So, adopting this calibration, in the next subsection we simulate the effects of a too low for too long interest rate policy, anticipated and unanticipated, to assess whether the model is able to generate a boom-bust event similar to the one of the 2000s in the U.S. Given the structure of the model, we can easily shut down equation (9) - setting $\alpha_{2}=0$ - and thus simulate the model for normal times; and, alternatively, setting $\alpha_{2}=24$ we can assess the role of the optimistic shadow banking system in the transmission of the too low for too long monetary policy.

yield and fed funds data have been converted to a quarterly periodicity with simple 3-month averages. Inflation is the year-on-year growth rate of the quarterly PCECTPI. The reported dynamic elasticities have been computed from the impulse response functions of a VAR(3) model estimated over 1954:Q3-2011:Q4. 


\subsection{Policy simulations}

Figures 5 and 6 plot the impulse response functions of selected variables to monetary policies of too low for too long interest rates, when the policy path is anticipated and unanticipated, respectively. The layout of the figures is identical. First, crossed lines correspond to responses of our model in normal times, while circled lines correspond to impulse responses in times of optimism. For the sake of comparison, we also report the impulse responses of the CMR-FA model (solid lines). Second, both figures have 3 panels: the top panel relates to aggregate variables, the middle one to variables relative to the safer entrepreneurs, and the bottom panel to variables relative to the riskier entrepreneurs.

A first broad conclusion from the comparison of the two figures is that anticipated policies generate a much larger and immediate response of the aggregate macroeconomic and most financial variables than unanticipated policies. This was expected and is entirely in line with what we have found for the models scrutinized in section 2.

A second general conclusion is that the effects of the too low for too long interest rate policy on macroeconomic variables - output, investment, inflation and price of capital - are very similar to those of the CMR-FA model, when our model with a shadow banking system is calibrated for normal times. This happens both for unanticipated and anticipated policies. Hence, when the spread in bond finance features a counter-cyclical behavior in line with the U.S. long-run average, our model does not improve on the CMR-FA model as regards predicting a dynamics of the price of capital and investment - let alone output and inflation - akin to the one seen in the boom and bust of the 2000s.

However, even in times of normal behavior of the spread in bond finance, our model adds relevant and reasonable results to the CMR-FA model. This is a third key conclusion. To see that, recall that the CMR-FA model predicts that a too low for too long interest rate policy leads to a fall in leverage and - especially when policy is unanticipated - a fall in loans (after an initial surge caused by the fact that the value of capital reacts more rapidly than the entrepreneurial net worth). In our model, the response of the riskier entrepreneurs' leverage is quite similar to the one predicted by the CMR-FA model (this is expected, since this part of the entrepreneurial sector closely follows the CMR-FA model). However, the safer entrepreneurs react differently: after a below-the-steady-state level for some quarters (caused by a stronger reaction of investment and the price of capital, compared to the reaction of their net worth), their leverage becomes higher than the steady-state level, and the amount of bonds reacts accordingly. Most importantly, the results from our model with a shadow banking system, even in its 
normal times version (crossed lines), are substantially new in the sense that the safer entrepreneurs are not merely crowding out finance from the riskier entrepreneurs. That is especially clear in figure 5, when the policy is anticipated: in fact, the total amount of finance in the economy (the sum of retail bank loans and investment banks bonds), after the initial increase on impact, is never below its steady-state level. In figure 6, when the policy path is unanticipated, the response of total finance is qualitatively similar to the one predicted by the CMR-FA model, but both the duration and the magnitude of the transitional period of below-the-steady-state total credit is quantitatively smaller than in the CMR-FA model.

At this point, we conclude that enhancing the state-of-the-art DSGE model with financial frictions associated to bond finance via a shadow banking system, while yielding more reasonable results, indicates that the policy of too low for too long interest rates has not been the only cause for the boom and bust of the U.S. in the 2000s. This was hardly unexpected, in view of the analyses mentioned at the outset of the paper stating that the 2000s' boom and bust resulted from the interaction of macro and micro factors. While the too low for too long monetary policy has been one crucial macro factor, it should be thought of as a trigger for the boom (and for the bust, when interrupted), that operated only because there were further necessary conditions present at the microeconomic level. Also motivated by this reason, we have set a version of the model for times of optimism in the shadow banking system, calibrated in line with the degree of over-optimism observed in the U.S. during the boom. We now turn to the analysis of that version (circled lines).

Let us consider first the simulation of an anticipated policy path (figure 5). The responses of the variables associated with the riskier entrepreneurs are not visibly different from those simulated with the CMR-FA model (the only exception is that the amount of loans jumps much more initially and then falls much more and is below the steady state for a very long period). As regards the safer entrepreneurs, optimism leads to an immediate and much larger fall in the bond coupon interest rate and in the bond finance spread. While the price of capital jumps, investment reacts with some lag due to adjustment costs - which, coupled with the jump in net worth, starts by decreasing leverage. But soon (a year after the announcement and beginning of the expansionary policy), as investment responds and the stock of capital increases rapidly and markedly, leverage rises above the steadystate level. The hump-shaped response of leverage puts it markedly above the steady-state level for a very long period, peaking at around 6 years after the beginning of policy. The amount of bonds underwritten reacts similarly to leverage and capital, with its hump at around 6 years more than 7 
percent above its steady-state level. ${ }^{15}$ In the aggregate, while not impacting strikingly on output and inflation, optimism induces a significantly larger hump-shaped reaction of investment, a vastly bigger increase in total credit (explained by the increase of bonds) and a somewhat higher initial jump of the price of capital. The subsequent dynamics of the price of capital is similar to the one seen in normal times, with a rapid decay to the steady-state level, but optimism induces levels slightly higher during the transition period. Overall, if the policy path is entirely anticipated by economic agents, our model with optimism in the shadow banking system creates the flavor of a boom and bust in some key variables, but does not produce the gradual build of the price of capital that is typically associated with booms and the period of asset prices below long-run equilibrium that is typically associated with busts.

The behavior of the model is quite different when agents do not anticipate the policy rate path (figure 6), especially regarding the safer entrepreneurs and some aggregate variables. As regards the riskier entrepreneurs, the only differences to the responses when policy is anticipated are that loans and leverage fall by a larger amount. Regarding the safer entrepreneurs, both the bond coupon interest rate and the spread in bond finance fall more gradually but end up lower at the end of the monetary ease (compared to when policy is anticipated) - in fact, much lower in the case of the spread. The initial fall in leverage is far smaller than when policy is anticipated; then, leverage starts increasing and becomes above the steady-state level quite faster; the peak of its hump occurs sooner, at 20 quarters, although at a slightly smaller level than when policy is anticipated. The amount of bonds underwritten reacts similarly to leverage and capital, increasing quire rapidly during the 2 years after the beginning of the policy of too low interest rates. The behavior of total credit is only slightly different, as it increases steadily for more than 7 years, not exhibiting the faltering in the second and third year after the beginning of the monetary ease that occurs when policy is anticipated. In the aggregate, again, optimism does not impact visibly on output and inflation, and while it induces a significantly larger hump-shaped reaction of investment, the magnitude of the rise in investment turns out to be inferior to the one found when policy is anticipated. Yet, the major difference happens in the dynamics of net worth and the price of capital: both jump on impact and keep on increasing until the end of the period of too low for too long interest rates - which does not happen without optimism; then, they both fall

\footnotetext{
15 Although not central for our purposes, a nice result of our model is that during the crisis - the period of sharp fall in asset prices and net worth - while bank loans are below their steady-state levels, the amount of bonds issued is above its long-run level (both when policy is anticipated and unanticipated). This is, to the best of our knowledge, the closer a DSGE model has come to the evidence reported by Adrian et al. (2012), who found that during crises bank lending to firms declines but bond financing increases.
} 
at a strong pace and, from quarter 20 onwards, they are persistently below their steady-state levels. Hence, if the policy path is not anticipated, our model with a shadow banking system and optimism is able to engender the gradual build of the price of capital that is typically associated with booms and the period of prices below long-run equilibrium that is typically associated with busts.

Our analysis therefore suggests that the boom and bust in the U.S. during the 2000s has been caused by the combination of three factors - a policy of too low for too long interest rates, a mood of excessive optimism and a failure of agents to anticipate the duration of the abnormally favorable macro conditions. ${ }^{16}$

\section{Concluding remarks}

In this paper we have assessed the role of a monetary policy of too low for too long interest rates as a trigger for a financial and economic boom, and then, when interrupted, as a trigger for a financial and economic bust.

The events of the 2000s in the U.S. were the key motivation for our analysis. Reviewing the FOMC decisions and statements after the 2001 recession, we argue that economic agents could hardly have anticipated the length and amplitude of the monetary ease. We thus conduct the analysis under both the more theoretically appealing scenario of an anticipated too low for too long policy path as well as the more pragmatic scenario of an unanticipated too low for too long policy path.

The study has been performed in the context of DSGE models and the method consisted of simulating anticipated and unanticipated policy paths of a constant policy interest rate 100 basis points below its steady-state level for 6 quarters, followed by an automatic shift of monetary policy to the Taylor-type policy rule.

\footnotetext{
${ }^{16}$ We have submitted the model to a number of sensitivity analyses, from which we emphasize two. The first relates to the persistence of optimism. In line with the literature on the persistence of beliefs, we have run all simulations of our model with $\rho_{\chi}=0.7$ instead of 0.9 . The turning points of the impulse response functions (for the safer entrepreneurs) of leverage, bonds issued, capital and bond spread turn out to occur sooner, but otherwise the results are qualitatively similar. The second relates to our assumption that the capital input $K_{t}$ in intermediate-good production is a composite of two entrepreneur-specific capital services: $K_{t}=\left[\eta\left(u_{t}^{H R, r} \bar{K}_{t}^{H R, r}\right)^{\rho}+(1-\eta)\left(u_{t}^{L R, l} \bar{K}_{t}^{L R, l}\right)^{\rho}\right]^{\frac{1}{\rho}}$, where $\rho$ denotes the degree of substitutability between the two entrepreneur-specific capital services. In all simulations we have considered $\rho=0.6$. However, given the inexistence of a sound literature to motivate the choice for the CES aggregator of capital stocks, we have run the simulations with two alternative values for $\rho$, namely $\rho=0.5$ and $\rho=0.7$. This parameter changes the bond to bank ratio in the steady state, which is unappealing ( 0.5 yields a bond/bank ratio of 1.78 and 0.7 a ratio of bond/bank equal to 1.12). The results change only quantitatively, with the effects of our shadow banking system increasing with the steady-state ratio of bond to bank finance.
} 
We started by showing that state-of-the-art DSGE models, even when including financial frictions, fail to predict a sizeable boom and bust after such policies. Moreover, they generate a fall in leverage during the period of booming investment, output and prices, which is clearly at odds with the data.

We then suggested a DSGE model with a second segment in the financial system, populated by investment banks that underwrite bonds issued by entrepreneurs with a low level of risk. We call this sector the shadow banking system, as we deem it as representing the variety of financial firms that has developed securitized finance under loose regulation and seemingly unlimited leverage in the run-up to the 2007 bust.

We modeled the spread in bond finance according to U.S. data, adopting a two tier approach. First, we calibrated the baseline (normal times) counter-cyclical behavior of the bond spread. Then, we calibrated the dynamics of the spread in periods of over-optimism.

Our model adds realism to the state-of-the-art DSGE model with financial frictions, as a too low for too long interest rates policy induces an increase in the leverage and bonds issued by the entrepreneurs that resort to the shadow banking system. The outcome of the model when the too low for too long interest rates policy is combined with a surge in optimism depends crucially on whether the policy path is anticipated or not by economic agents.

When the policy is anticipated, the model comes a step further to predict a boom and bust, as total credit (bank loans plus bonds), investment and the price of capital increase substantially more than without optimism or in alternative models. However, the price of capital does not feature the gradual build that is typically associated with booms nor the below-average levels typically associated with busts. In turn, when the policy path is unanticipated, the model generates a boom-bust dynamics: (i) output, investment and total credit increase and respond in a hump-shaped pattern; (ii) the price of capital rises steadily while the policy interest rate is too low, and then falls abruptly to below its steady-state level.

Our model thus suggests that the boom and bust in the U.S. during the 2000s has been caused by the combination of three factors - a policy of too low for too long interest rates, a mood of excessive optimism and a failure of agents to anticipate the duration of the abnormally favorable macro conditions. One may conjecture that the misperception about the length of the benign macroeconomic environment could be related with a failure of the FED to clearly communicate its intentions.

As corollaries, we draw two lessons for monetary policy. First, it seems warranted that spreads in the 
bond market should be given a more important role in the conduct and monitoring of monetary policy: spreads substantially below historical levels are associated with over-confidence, under-estimation of risk, excessive leverage and an increasing likelihood of a bust - and therefore should trigger some monetary policy tightening. Second, it seems crucial that policy-makers build a strong credibility and communicate policies with the maximum transparency: when agents are able to anticipate the policy path, the reaction of financial and macroeconomic variables is faster and maybe larger, but the likelihood of uncontrollable booms and busts seems smaller. 


\begin{tabular}{|c|c|c|}
\hline FOMC Meeting & FFR target & Statement \\
\hline \multicolumn{3}{|l|}{ A: 2003-2004 } \\
\hline 2003-June & $\begin{array}{l}\searrow 25 b p \\
\text { to } 1 \%\end{array}$ & $\begin{array}{l}\text { a slightly more expansive monetary policy would add further } \\
\text { support for an economy which it expects to improve over time }\end{array}$ \\
\hline $\begin{array}{l}\text { from 2003-August } \\
\text { until 2003-December }\end{array}$ & $\leftrightarrow$ at $1 \%$ & $\begin{array}{l}\text { policy accommodation can be maintained for a } \\
\text { considerable period }\end{array}$ \\
\hline $\begin{array}{l}\text { 2004-January } \\
\text { 2004-March }\end{array}$ & $\leftrightarrow$ at $1 \%$ & $\begin{array}{l}\text { [the FOMC] can be patient in removing } \\
\text { its policy accommodation }\end{array}$ \\
\hline 2004-May & $\leftrightarrow$ at $1 \%$ & $\begin{array}{l}\text { policy accommodation can be removed at a pace that is } \\
\text { likely to be measured }\end{array}$ \\
\hline 2004-June & $\begin{array}{l}\nearrow 25 b p \\
\text { to } 1.25 \%\end{array}$ & $\begin{array}{l}\text { policy accommodation can be removed at a pace that is } \\
\text { likely to be measured }\end{array}$ \\
\hline \multicolumn{3}{|l|}{ B: 2008-2012 } \\
\hline 2008-December & $\begin{array}{l}\text { from } 1 \% \searrow \\
\text { to }[0 ; 0.25] \%\end{array}$ & $\begin{array}{l}\text { the Committee anticipates that weak economic conditions } \\
\text { are likely to warrant exceptionally low levels } \\
\text { of the federal funds rate for some time }\end{array}$ \\
\hline 2009-January & $\begin{array}{l}\leftrightarrow \text { at } \\
{[0 ; 0.25] \%}\end{array}$ & $\begin{array}{l}\text { the Committee anticipates that weak economic conditions } \\
\text { are likely to warrant exceptionally low levels } \\
\text { of the federal funds rate for some time }\end{array}$ \\
\hline $\begin{array}{l}\text { from 2009-March } \\
\text { until 2011-June }\end{array}$ & $\begin{array}{l}\leftrightarrow \text { at } \\
{[0 ; 0.25] \%}\end{array}$ & $\begin{array}{l}\text { the Committee anticipates that weak economic conditions } \\
\text { are likely to warrant exceptionally low levels } \\
\text { of the federal funds rate for an extended period }\end{array}$ \\
\hline $\begin{array}{l}\text { from 2011-August } \\
\text { until 2011-December }\end{array}$ & $\begin{array}{c}\leftrightarrow \text { at } \\
{[0 ; 0.25] \%}\end{array}$ & $\begin{array}{l}\text { the Committee anticipates that economic conditions [...] } \\
\text { are likely to warrant exceptionally low levels } \\
\text { for the federal funds rate at least through mid-2013 }\end{array}$ \\
\hline since 2012-January & $\begin{array}{c}\leftrightarrow \text { at } \\
{[0 ; 0.25] \%}\end{array}$ & $\begin{array}{l}\text { the Committee anticipates that economic conditions [...] } \\
\text { are likely to warrant exceptionally low levels } \\
\text { for the federal funds rate at least through late } 2014\end{array}$ \\
\hline
\end{tabular}

Table 1: FOMC decisions and statements in selected periods of the $2000 \mathrm{~s}$

Note. FOMC: Federal Open Market Committee. FFR: Fed Funds Rate. Source: http://www.federalreserve.gov 


\begin{tabular}{|c|c|c|c|}
\hline Households & Value & Source & Description \\
\hline$\overline{\bar{\beta}}$ & 0.9875 & our calibration & discount factor \\
\hline$\psi_{L}$ & $(36)$ & (endogenous) & weight on disutility of labor \\
\hline$\sigma_{L}$ & 1 & CMR & curvature of disutility of labor \\
\hline$b$ & 0.63 & CMR & habit persistence in consumption \\
\hline$\xi_{w}$ & 0.75 & Erceg et al. (2000) & fraction of households that cannot reoptimize wage \\
\hline$\lambda_{w}$ & 1.05 & CMR & markup, workers \\
\hline$\iota_{w 1}$ & 0.29 & CMR & weight of wage indexation to steady-state inflation \\
\hline \multicolumn{4}{|l|}{ Firms } \\
\hline$\alpha$ & 0.36 & Levin et al. (2005) & capital share in the production function \\
\hline$\xi_{p}$ & 0.75 & Erceg et al. (2000) & fraction of firms that cannot reoptimize price \\
\hline$\iota_{1}$ & 0.16 & CMR & weight of price indexation to steady-state inflation \\
\hline$\lambda_{f}$ & 1.2 & CMR & markup, intermediate-good firms \\
\hline$S^{\prime \prime}$ & 29.3 & CMR & curvature of investment adjustment cost function \\
\hline$\delta$ & 0.03 & CMR & depreciation rate on capital \\
\hline$\rho$ & 0.6 & our calibration & degree of substitutability between capital services \\
\hline \multicolumn{4}{|l|}{ Entrepreneurs } \\
\hline$\sigma_{a}^{H R}, \sigma_{a}^{L R}$ & 18.9 & CMR & curvature of capital utilization cost functions \\
\hline$\mu$ & 0.15 & our calibration & fraction of realized profits lost in bankruptcy \\
\hline$\sigma$ & $\sqrt{0.3}$ & our calibration & standard deviation of productivity shock \\
\hline$W^{e, H R, r}, W^{e, L R, l}$ & 0.02 & CMR & transfer from households \\
\hline$\gamma^{L R}$ & 0.96 & our calibration & survival probability of safer entrepreneurs \\
\hline$\gamma^{H R}$ & 0.97 & our calibration & survival probability of riskier entrepreneurs \\
\hline$\eta$ & 0.2772 & our calibration & share of riskier entrepreneurs \\
\hline \multicolumn{4}{|l|}{ Bond Market } \\
\hline $\bar{\varepsilon}$ & 510 & Chen et al. (2007) & steady-state elasticity of the demand for funds \\
\hline$\alpha_{1}$ & 30000 & our calibration & sensitivity of elasticity to output gap \\
\hline$\rho_{x}$ & 0.9 & Kurz and Motolese (2011) & persistence in optimism \\
\hline$\alpha_{2}$ & 24 & our calibration & sensitivity of optimism to entrepreneur's net worth \\
\hline $\bar{\chi}$ & 0 & our calibration & steady-state level of optimism \\
\hline \multicolumn{4}{|l|}{$\overline{\text { Policy }}$} \\
\hline$\tilde{\rho}$ & 0.88 & CMR & interest rate smoothing \\
\hline$\alpha_{\pi}$ & 1.82 & CMR & weight of expected inflation in Taylor rule \\
\hline$\alpha_{y}$ & 0.11 & CMR & weight of output gap in Taylor rule \\
\hline$\eta_{g}$ & 0.2 & CMR & share of government consumption \\
\hline
\end{tabular}

Table 2: Model parameters (time unit of model: quarterly)

Note. For a complete description of the model, see Verona et al. (2012, appendix A) 


\begin{tabular}{|c||c|c|}
\hline Variable & Model & U.S. data \\
\hline \hline$K / Y$ & 5.46 & 10.7 \\
\hline$C / Y$ & 0.63 & 0.56 \\
\hline$I / Y$ & 0.17 & 0.25 \\
\hline$G / Y$ & 0.2 & 0.2 \\
\hline \multirow{2}{*}{ leverage ratio $=Q \bar{K} / N^{1}$} & safer 1.26 & \\
& riskier 1.35 & \\
\hline bond to bank finance ratio $^{2}$ & $\mathbf{1 . 5 1 5 2}$ & $\mathbf{1 . 5 1 5 2}$ \\
\hline
\end{tabular}

Table 3: Steady-State Properties, Model versus U.S. Data

Note. When not specified, the source for U.S. data is CMR and the sample period is 1998Q4-2003Q4. ${ }^{1}$ CMR compute the leverage as $N /(Q \bar{K}-N)$. We compute the leverage as in Bernanke et al. (1999). ${ }^{2}$ Source: De Fiore and Uhlig (2011). They report a ratio of bank to bond finance of 0.66 in 1999-2007.

\begin{tabular}{|c||c|c|}
\hline \multicolumn{1}{|c||}{ Variable } & Model & U.S. data \\
\hline \hline \multirow{2}{*}{ Rate of return on capital, $R^{k}$} & safer $11.38 \%$ & \\
& riskier $8.40 \%$ & $10.32 \%$ \\
\hline Cost of external finance, $Z$ & $6.81 \%$ & {$[7.1 ; 8.1] \%$} \\
\hline Time deposit, $R^{e}$ & $5.16 \%$ & $5.12 \%$ \\
\hline Cost of bond finance, $R^{\text {coupon }}$ & $5.99 \%$ & $5.96 \%^{1}$ \\
\hline
\end{tabular}

Table 4: Interest Rates, Model versus U.S. Data

Note. When not specified, the source for U.S. data is CMR and the sample period is 1987Q1-2003Q4. ${ }^{1}$ Chen et al. (2007) find an average yield spread of $A A A$ bonds over the period 1995-2003 of 84 basis points. Adding this spread to the risk-free rate $\left(R^{e}\right)$ gives the value displayed in the table. 


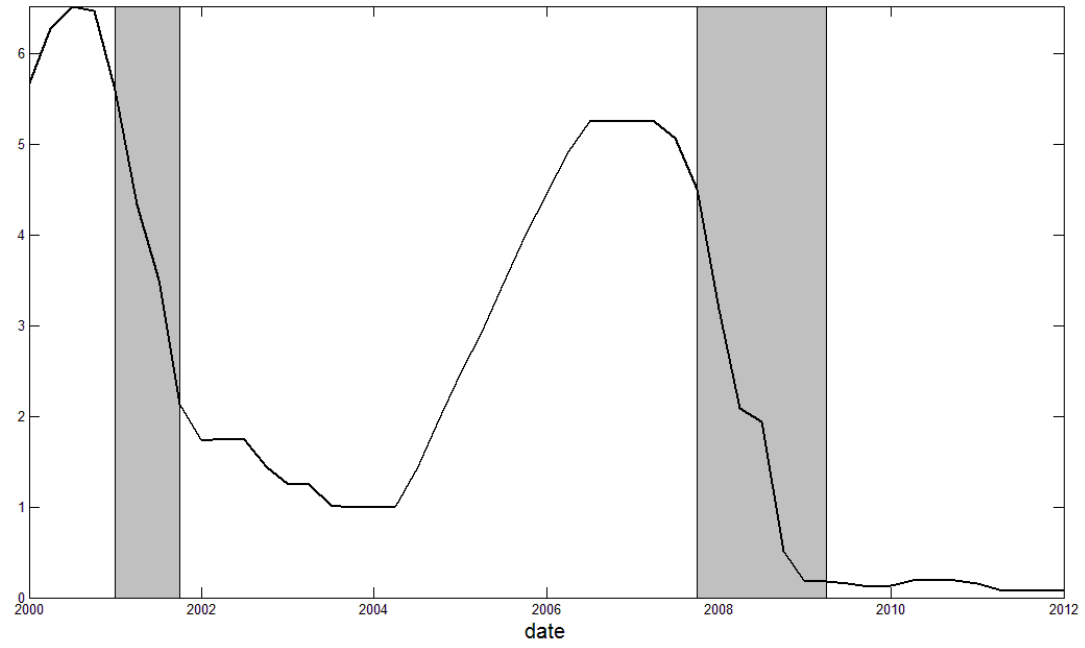

Figure 1: Effective federal funds rate in the 2000s Note. Grey bars denote NBER recessions. 


\section{A. Anticipated policy}
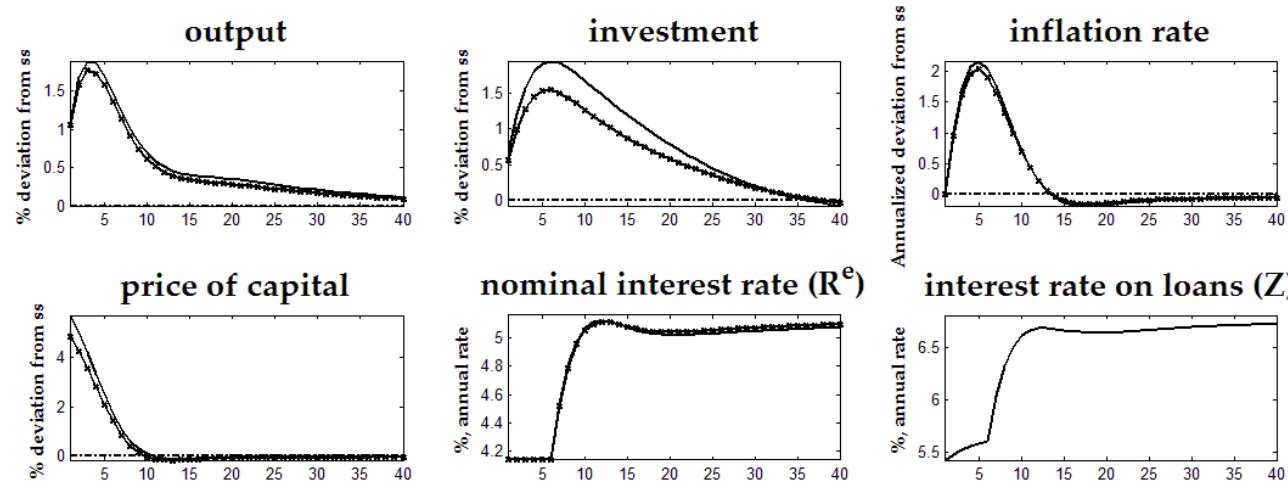

nominal interest rate $\left(R^{e}\right)$

interest rate on loans $(\mathrm{Z})$
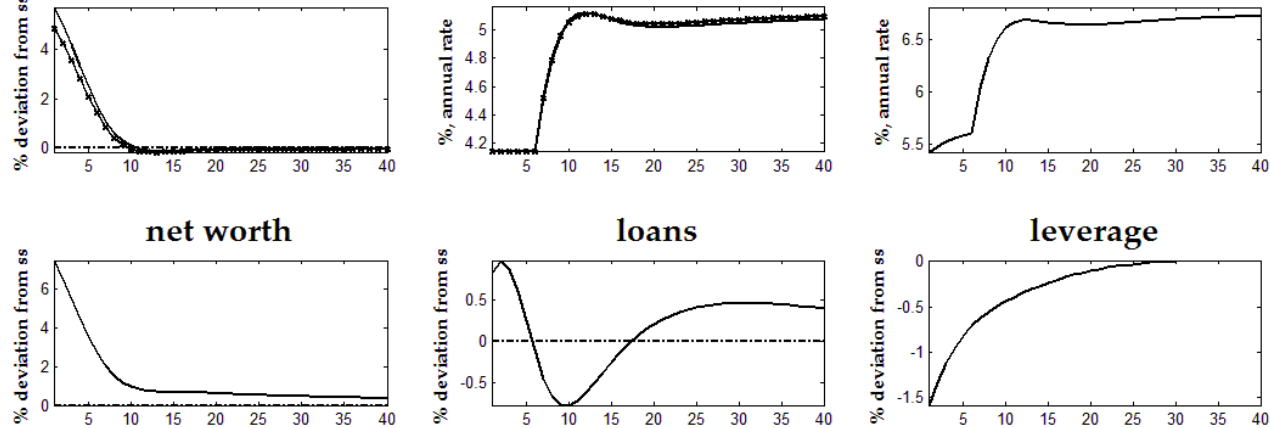

\section{B. Unanticipated policy}
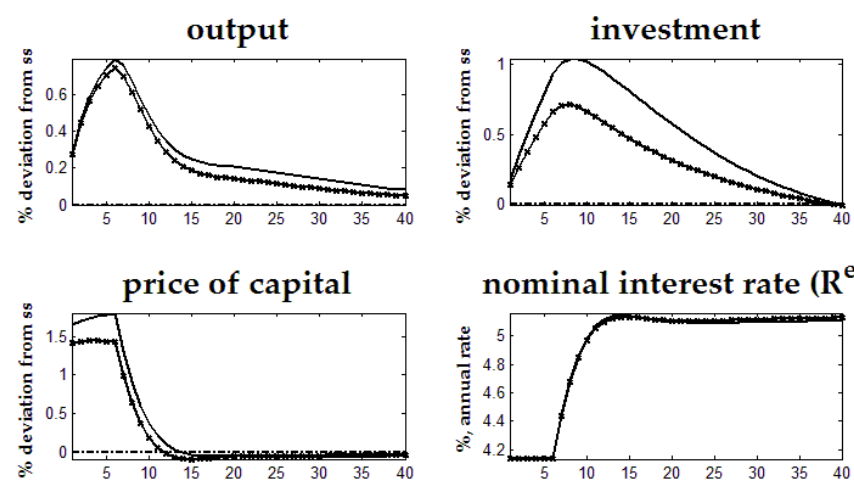

nominal interest rate $\left(\mathrm{R}^{\mathrm{e}}\right)$
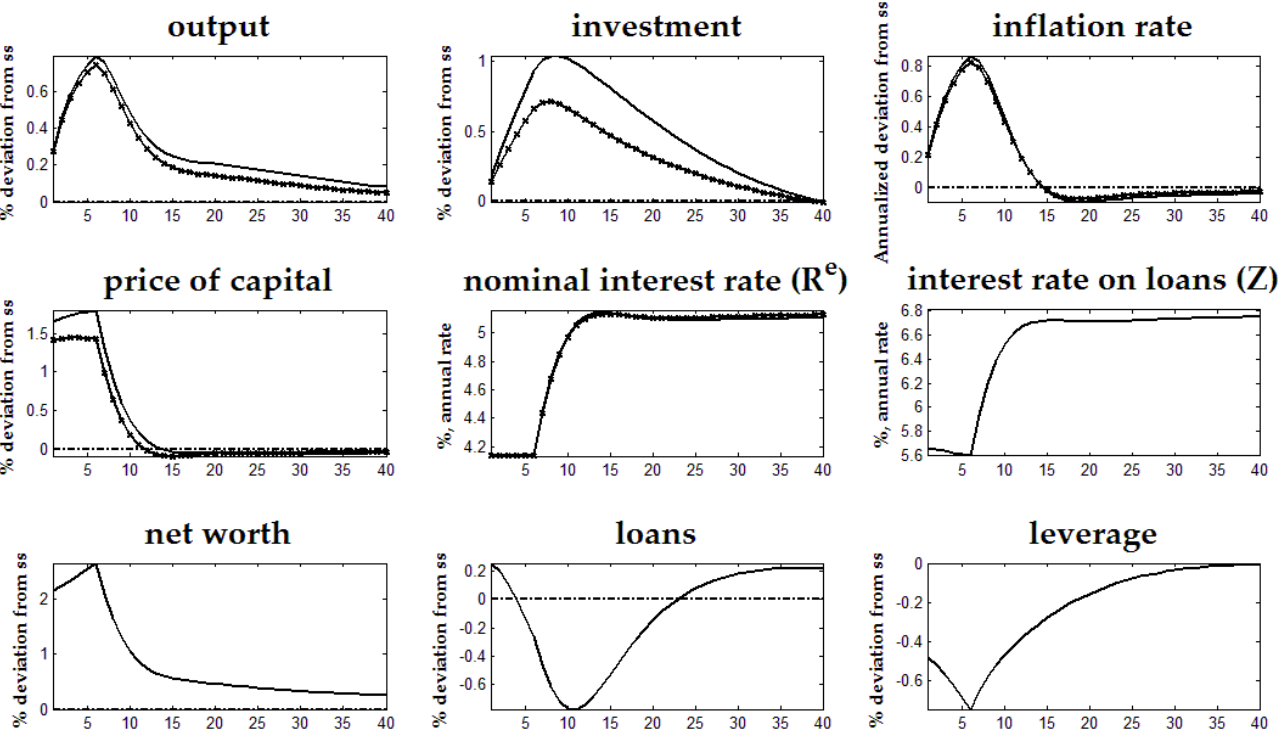

Figure 2: Monetary policy of too low for too long interest rates in CMR

Note. Values expressed as percentage deviation from steady-state values. Inflation is expressed as annualized percent deviation from its steady state and the interest rates are expressed as annual percentage points. CMR-FA model: solid lines. CMR-Simple model: crossed lines. Steady state: dashed-dotted lines. 


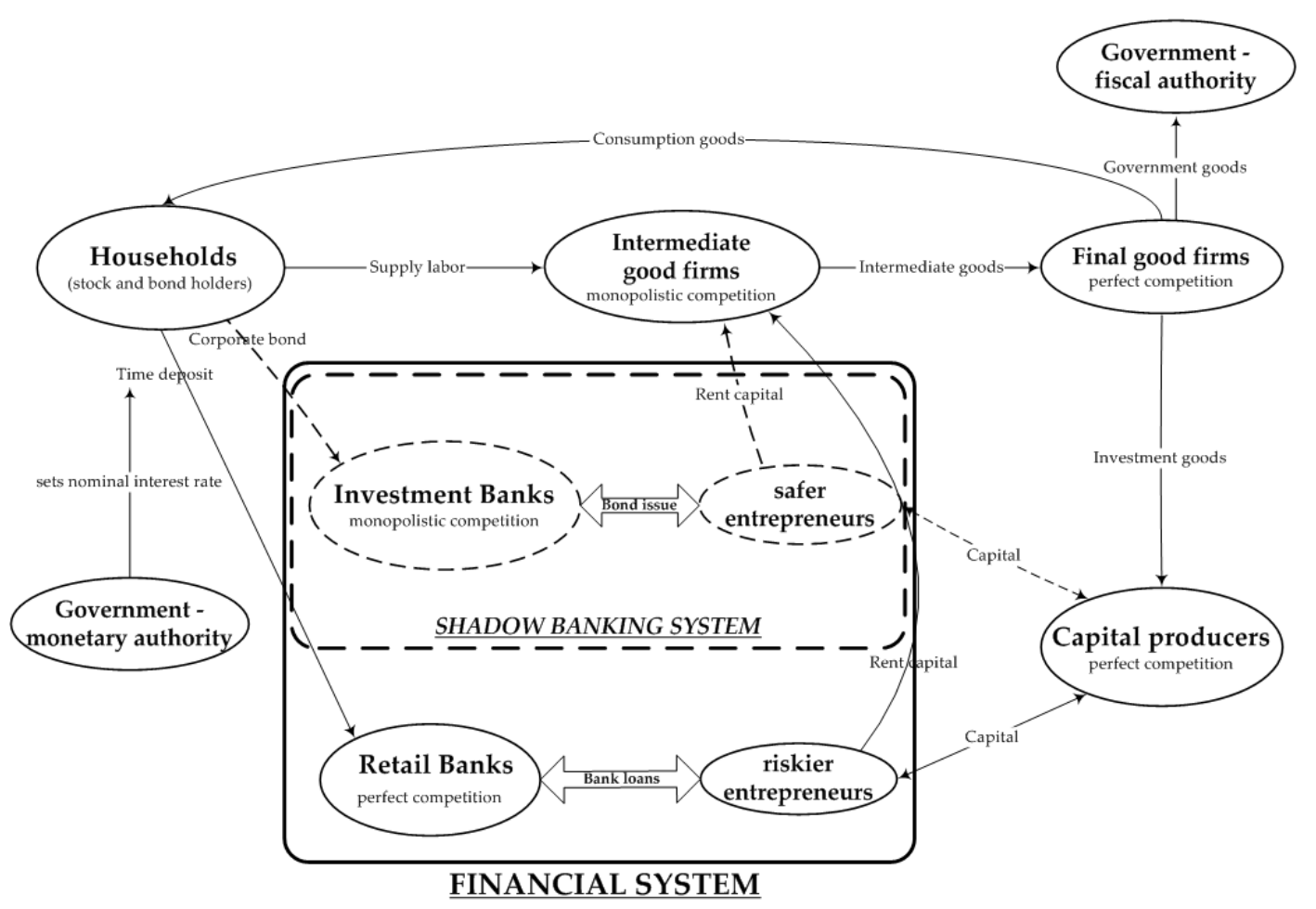

Figure 3: Structure of the model

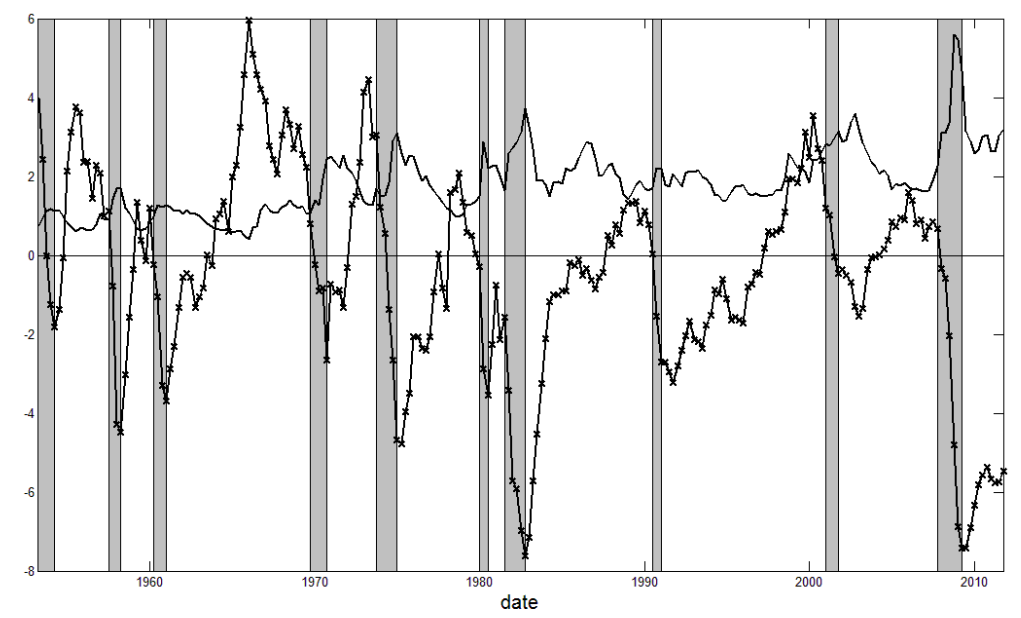

Figure 4: BAA spread and output gap

Note. BAA spread: solid line. Output gap: crossed line. Grey bars denote NBER recessions. 


\section{A. Aggregate variables}
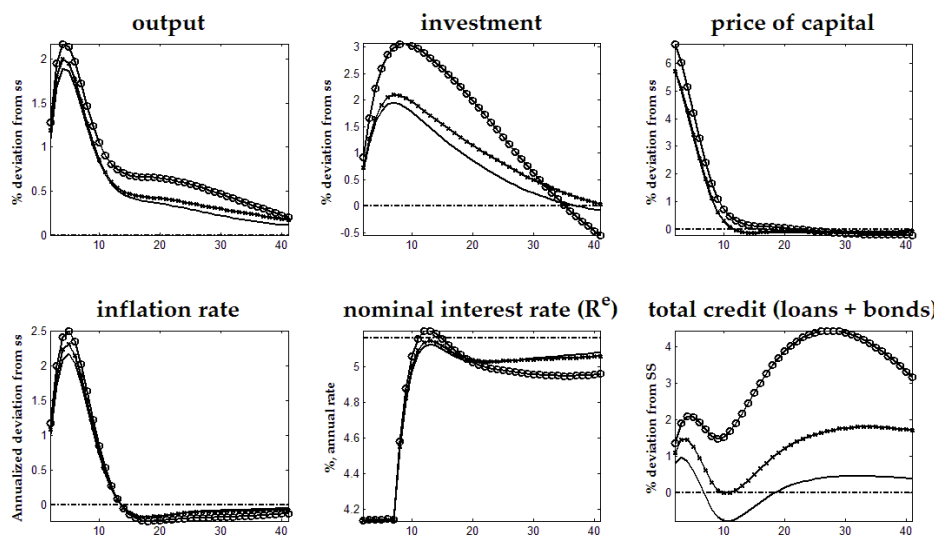

\section{B. Safer entrepreneurs}
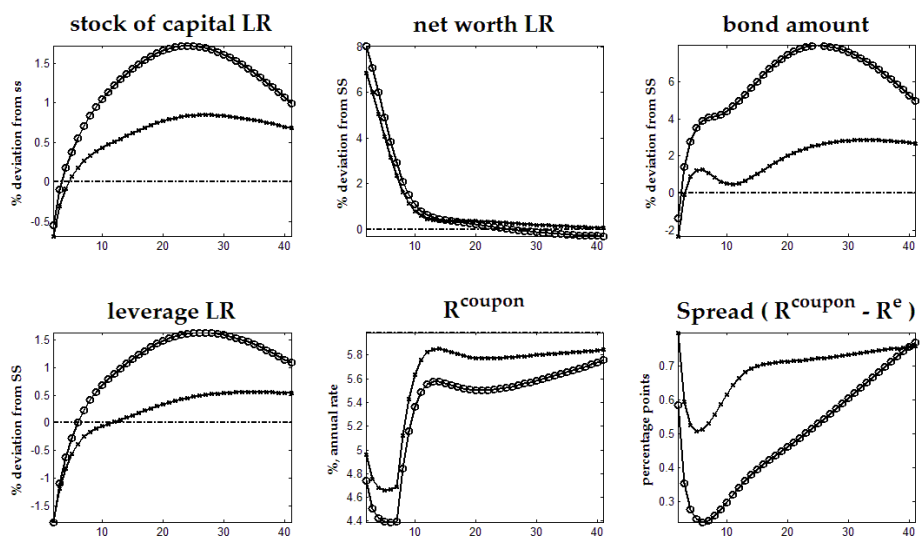

\section{Riskier entrepreneurs}
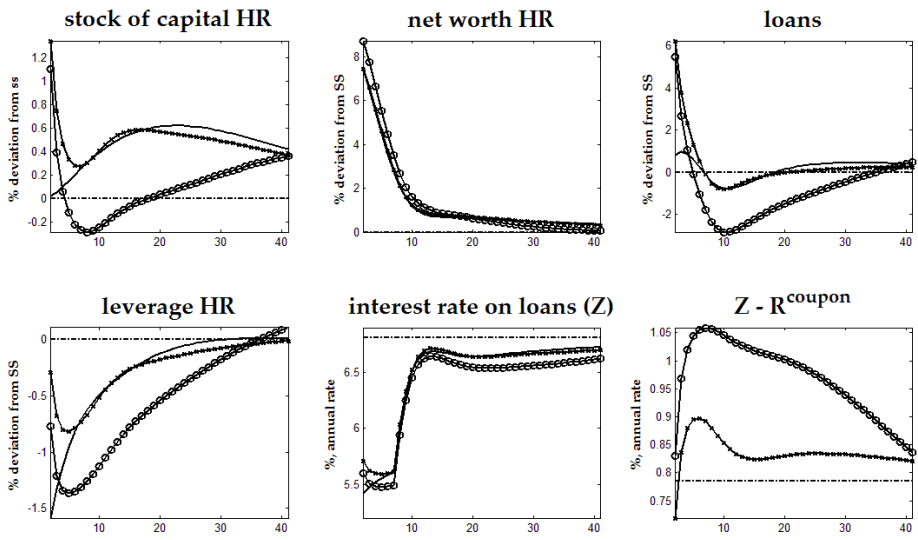

Figure 5: Anticipated monetary policy of too low for too long interest rates

Note. Values expressed as percentage deviation from steady-state values. Inflation is expressed as annualized percent deviation from its steady state and the interest rates are expressed as annual percentage points. Our model in normal times: crossed lines. Our model in optimistic times: circled lines. CMR-FA model: solid lines. Steady state: dasheddotted lines. Baseline parameters: see table 2. 


\section{A. Aggregate variables}
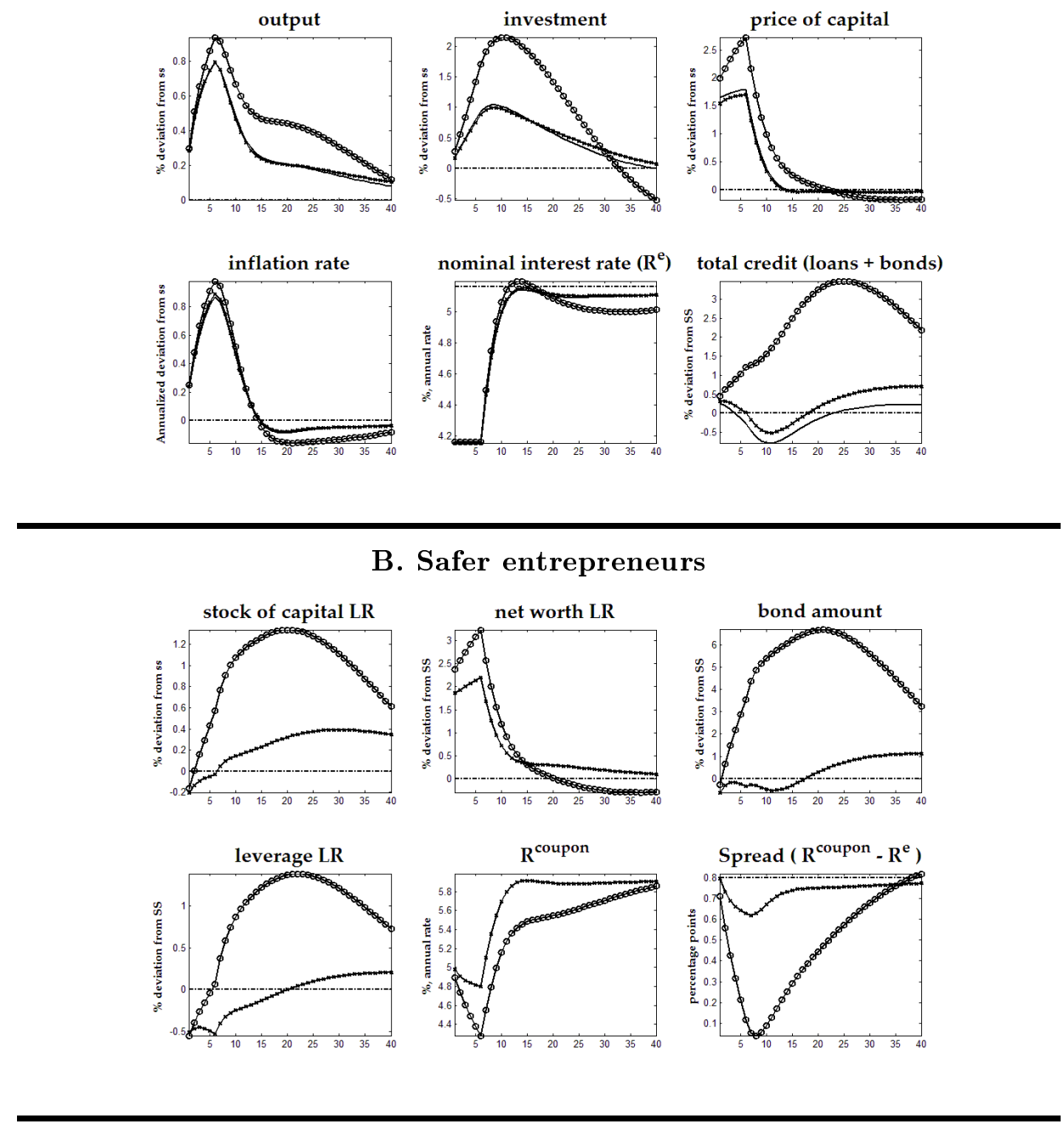

C. Riskier entrepreneurs
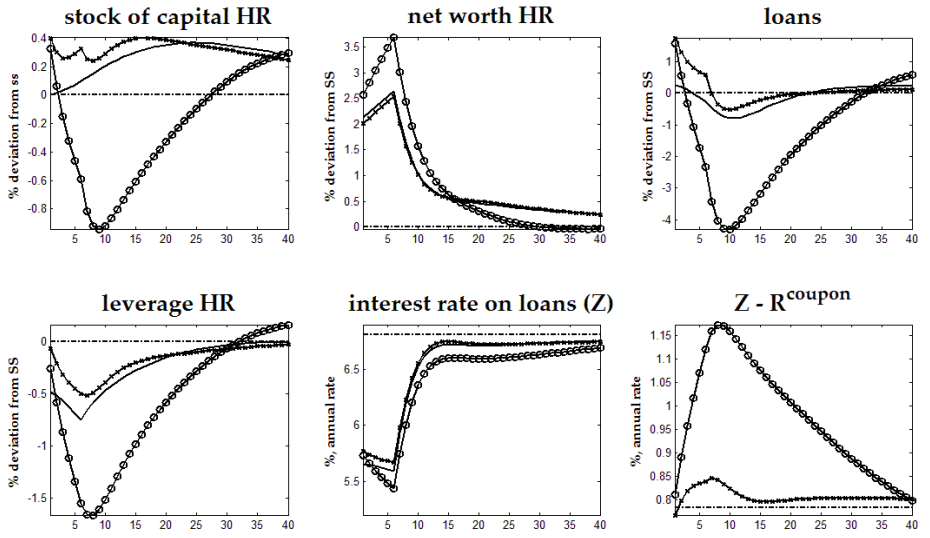

Figure 6: Unanticipated monetary policy of too low for too long interest rates

Note. Values expressed as percentage deviation from steady-state values. Inflation is expressed as annualized percent deviation from its steady state and the interest rates are expressed as annual percentage points. Our model in normal times: crossed lines. Our model in optimistic times: circled lines. CMR-FA model: solid lines. Steady state: dasheddotted lines. Baseline parameters: see table 2. 


\section{References}

Adrian, T., P. Colla, and H. S. Shin: 2012, 'Which Financial Frictions? Parsing the Evidence from the Financial Crisis of 2007-9'. In: NBER Macroeconomics Annual 2012, Volume 27, NBER Chapters. National Bureau of Economic Research.

Bean, C., M. Paustian, A. Penalver, and T. Taylor: 2010, 'Monetary Policy after the Fall'. Paper presented at the 2010 Jackson Hole Symposium "Macroeconomic Challenges: The Decade Ahead", Jackson Hole, Wyoming.

Berlin, M. and J. Loeys: 1988, 'Bond Covenants and Delegated Monitoring'. Journal of Finance 43(2), $397-412$.

Bernanke, B. S.: 2010, 'Causes of the Recent Financial and Economic Crisis'. testimony before the Financial Crisis Inquiry Commission, Washington, D.C., September 2.

Bernanke, B. S., M. Gertler, and S. Gilchrist: 1999, 'The financial accelerator in a quantitative business cycle framework'. In: J. B. Taylor and M. Woodford (eds.): Handbook of Macroeconomics, Vol. 1. Elsevier, Chapt. 21, pp. 1341-1393.

Bernanke, B. S., M. Gertler, and M. Watson: 1997, 'Systematic Monetary Policy and the Effects of Oil Price Shocks'. Brookings Papers on Economic Activity 28(1), 91-157.

Bernanke, B. S., M. Gertler, and M. Watson: 2004, 'Oil Shocks and Aggregate Macroeconomic Behavior: The Role of Monetary Policy: Reply'. Journal of Money, Credit and Banking 36(2), 287-291.

Blanchard, O.: 2009, 'The crisis: basic mechanisms, and appropriate policies'. IMF Working Paper 09/80, International Monetary Fund.

Bolton, P. and X. Freixas: 2000, 'Equity, Bonds, and Bank Debt: Capital Structure and Financial Market Equilibrium under Asymmetric Information'. Journal of Political Economy 108(2), 324-351.

Bolton, P. and X. Freixas: 2006, 'Corporate Finance and the Monetary Transmission Mechanism'. The Review of Financial Studies 19(3), 829-870. 
Borio, C.: 2008, 'The financial turmoil of 2007-?: a preliminary assessment and some policy considerations'. BIS Working Papers 251, Bank for International Settlements.

Brunnermeier, M. K.: 2009, 'Deciphering the Liquidity and Credit Crunch 2007-08'. Journal of Economic Perspective 23(1), 77-100.

Chemmanur, T. J. and P. Fulghieri: 1994, 'Investment Bank Reputation, Information Production, and Financial Intermediation'. Journal of Finance 49(1), 57-79.

Chen, L., D. A. Lesmond, and J. Wei: 2007, 'Corporate Yield Spreads and Bond Liquidity'. Journal of Finance 62(1), 119-149.

Christiano, L. J., M. Eichenbaum, and C. L. Evans: 2005, 'Nominal Rigidities and the Dynamic Effects of a Shock to Monetary Policy'. Journal of Political Economy 113(1), 1-45.

Christiano, L. J., R. Motto, and M. Rostagno: 2003, 'The Great Depression and the Friedman-Schwartz Hypothesis'. Journal of Money, Credit, and Banking 35(6 - part 2), 1119-1197.

Christiano, L. J., R. Motto, and M. Rostagno: 2008, 'Shocks, Structures or Monetary Policies? The Euro Area and US After 2001'. Journal of Economic Dynamics and Control 32(8), 2476-2506.

Christiano, L. J., R. Motto, and M. Rostagno: 2010, 'Financial factors in economic fluctuations'. Working Paper Series 1192, European Central Bank.

Curdia, V. and M. Woodford: 2010, 'Credit Spreads and Monetary Policy'. Journal of Money, Credit, and Banking 42(Supplement s1), 3-35.

De Fiore, F. and H. Uhlig: 2011, 'Bank Finance versus Bond Finance'. Journal of Money, Credit and Banking 43(7), 1399-1421.

de Larosiere, J.: 2010, 'Monetary Policy has played a major role in the run up to the financial crisis'. Speech delivered at Columbia University, December 1st 2010.

de Larosiere, J., L. Balcerowicz, O. Issing, R. Masera, C. Mc Carthy, L. Nyberg, J. Perez, and O. Ruding: 2009, 'The High-Level Group on Financial Supervision in the EU'. Technical report, The de Larosiere Group.

de Walque, G., O. Pierrard, and A. Rouabah: 2010, 'Financial (in)stability, supervision and liquidity injections: a dynamic general equilibrium approach'. The Economic Journal 120(549), 1234-1261. 
Diamond, D. W.: 1991, 'Monitoring and Reputation: The Choice between Bank Loans and Directly Placed Debt'. Journal of Political Economy 99(4), 689-721.

Ellis, K., R. Michaely, and M. O'Hara: 2000, 'When the Underwriter Is the Market Maker: An Examination of Trading in the IPO Aftermarket'. Journal of Finance 55(3), 1039-1074.

Erceg, C. J., L. Guerrieri, and C. Gust: 2006, 'SIGMA: A New Open Economy Model for Policy Analysis'. International Journal of Central Banking 2(1), 1-50.

Erceg, C. J., D. W. Henderson, and A. T. Levin: 2000, 'Optimal Monetary Policy with Staggered Wage and Price Contracts'. Journal of Monetary Economics 46(2), 281-313.

Fang, L. H.: 2005, 'Investment Bank Reputation and the Price and Quality of Underwriting Services'. Journal of Finance 60(6), 2729-2761.

Fisher, I.: 1933, 'The Debt-Deflation Theory of Great Depressions'. Econometrica 1(4), 337-357.

Friedman, B. M. and K. N. Kuttner: 1998, 'Indicator Properties Of The Paper-Bill Spread: Lessons From Recent Experience'. The Review of Economics and Statistics 80(1), 34-44.

Gerali, A., S. Neri, L. Sessa, and F. M. Signoretti: 2010, 'Credit and Banking in a DSGE Model of the Euro Area'. Journal of Money, Credit, and Banking 42(6), 107-141.

Gertler, M. and P. Karadi: 2011, 'A model of unconventional monetary policy'. Journal of Monetary Economics 58(1), 17-34.

Gertler, M. and C. S. Lown: 1999, 'The Information in the High-Yield Bond Spread for the Business Cycle: Evidence and Some Implications'. Oxford Review of Economic Policy 15(3), 132-150.

Gilchrist, S., V. Yankov, and E. Zakrajsek: 2009. Journal of Monetary Economics 56(4), 471-493.

Gilchrist, S. and E. Zakrajsek: 2012a, 'Credit Spreads and Business Cycle Fluctuations'. American Economic Review. Forthcoming.

Gilchrist, S. and E. Zakrajsek: 2012b, 'Monetary Policy and Credit Supply Shocks'. IMF Economic Review. Forthcoming.

Goodfriend, M. and B. T. McCallum: 2007, 'Banking and interest rates in monetary policy analysis: A quantitative exploration'. Journal of Monetary Economics 54(5), 1480-1507. 
Hale, G.: 2007, 'Bonds or Loans? The Effect of Macroeconomic Fundamentals'. Economic Journal 117, $196-215$.

Harrison, R., K. Nikolov, M. Quinn, G. Ramsay, A. Scott, and R. Thomas: 2005, 'The Bank of England Quarterly Model'. Technical report, Bank of England.

Holmstrom, B. and J. Tirole: 1997, 'Financial Intermediation, Loanable Funds, and the Real Sector'. The Quarterly Journal of Economics 112(3), 663-691.

Iacoviello, M.: 2005, 'House Prices, Borrowing Constraints, and Monetary Policy in the Business Cycle'. American Economic Review 95(3), 739-764.

Kiyotaki, N. and J. Moore: 1997, 'Credit Cycles'. Journal of Political Economy 105(2), 211-248.

Kobayashi, T.: 2008, 'Incomplete Interest Rate Pass-Through and Optimal Monetary Policy'. International Journal of Central Banking 4(3), 77-118.

Kurz, M. and M. Motolese: 2011, 'Diverse beliefs and time variability of risk premia'. Economic Theory 47(2), 293-335.

Lambertini, L., C. Mendicino, and M. T. Punzi: 2011, 'Leaning Against Boom-Bust Cycles in Credit and Housing Prices'. Working Papers 8 | 2011, Banco de Portugal.

Lambertini, L., C. Mendicino, and M. T. Punzi: 2012, 'Expectations-driven cycles in the housing market'. Research Discussion Papers 2/2012, Bank of Finland.

Laseen, S. and L. E. Svensson: 2011, 'Anticipated Alternative policy Rate Paths in Policy Simulations'. International Journal of Central Banking 7(3), 1-35.

Levin, A. T., A. Onatski, J. C. Williams, and N. Williams: 2005, 'Monetary Policy Under Uncertainty in Micro-Founded Macroeconometric Models'. NBER Working Papers 11523, National Bureau of Economic Research.

McCulley, P.: 2007, 'Teton Reflection'. PIMCO, Global Central Bank Focus, August/September 2007, available at http://www.pimco.com/Documents/GCB

Meh, C. A. and K. Moran: 2010, 'The role of bank capital in the propagation of shocks'. Journal of Economic Dynamics \& Control 34(3), 555-576. 
Milani, F. and J. Treadwell: 2012, 'The Effects of Monetary Policy "News" and "Surprises"'. Journal of Money, Credit and Banking. Forthcoming.

Pozsar, Z., T. Adrian, A. Ashcraft, and H. Boesky: 2010, 'Shadow banking'. Staff Reports 458, Federal Reserve Bank of New York.

Reis, R.: 2009, 'A Sticky-information General Equilibrium Model for Policy Analysis'. In: K. SchmidtHebbel, C. Walsh, and N. Loayza (eds.): Monetary Policy under Uncertainty and Learning, Vol. 13. Chapt. 8, pp. 227-283.

Semmler, W. and L. Bernard: 2012, 'Boom-Bust Cycles: Leveraging, Complex Securities, and Asset Prices'. Journal of Economic Behavior \&3 Organization 81, 442-465.

Sims, C. A. and T. Zha: 2006, 'Does Monetary Policy Generate Recessions?'. Macroeconomic Dynamics 10(02), 231-272.

Smets, F. and R. Wouters: 2003, 'An Estimated Stochastic Dynamic General Equilibrium Model of the Euro Area'. The Journal of the European Economic Association 1(5), 1123-1175.

Taylor, J. B.: 2009, Getting Off Track - How Government Actions and Interventions Caused, Prolonged, and Worsened the Financial Crisis. Hoover Institution, Stanford University, California.

Taylor, J. B.: 2010, 'Commentary: Monetary Policy after the Fall'. Speech delivered at the 2010 Jackson Hole Symposium "Macroeconomic Challenges: The Decade Ahead", Jackson Hole, Wyoming.

Trichet, J.-C.: 2009, 'The global dimension of the crisis'. speech delivered at the Foreign Correspondents' Club of Japan, Tokyo, April 18, 2009.

Van den Heuvel, S. J.: 2008, 'The welfare cost of bank capital requirements'. Journal of Monetary Economics 55(2), 298-320.

Verona, F., M. M. F. Martins, and I. Drumond: 2012, '(Un)anticipated monetary policy in a DSGE model with a shadow banking system'. CEF.UP Working Paper 2011-01, revised June 2012, Universidade do Porto, Faculdade de Economia do Porto, available at http://cefup.fep.up.pt/uploads/WorkingPapers/2011-01-wp-rev-June2012.pdf. 